
10. Nordic Council
of Ministers

\title{
Arctic Tourism in Times of Change: Seasonality
}

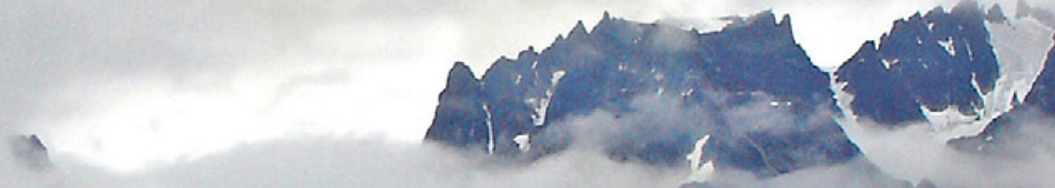

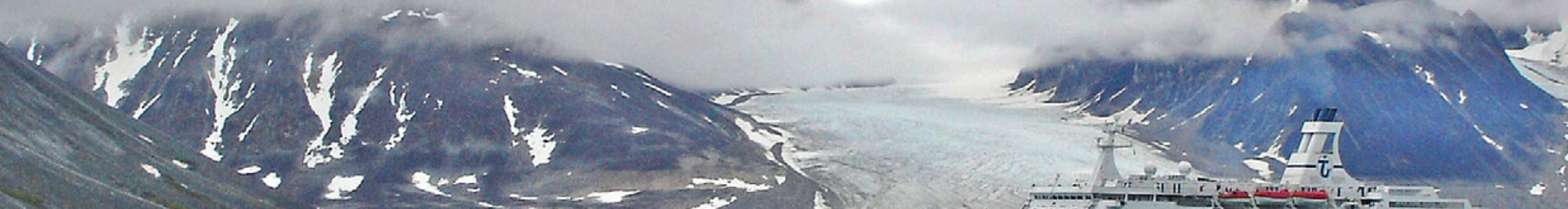

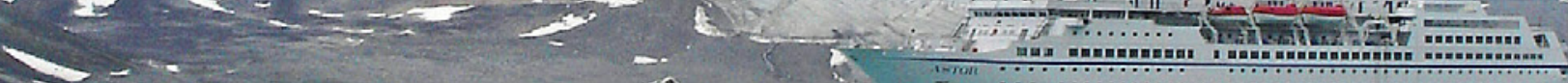

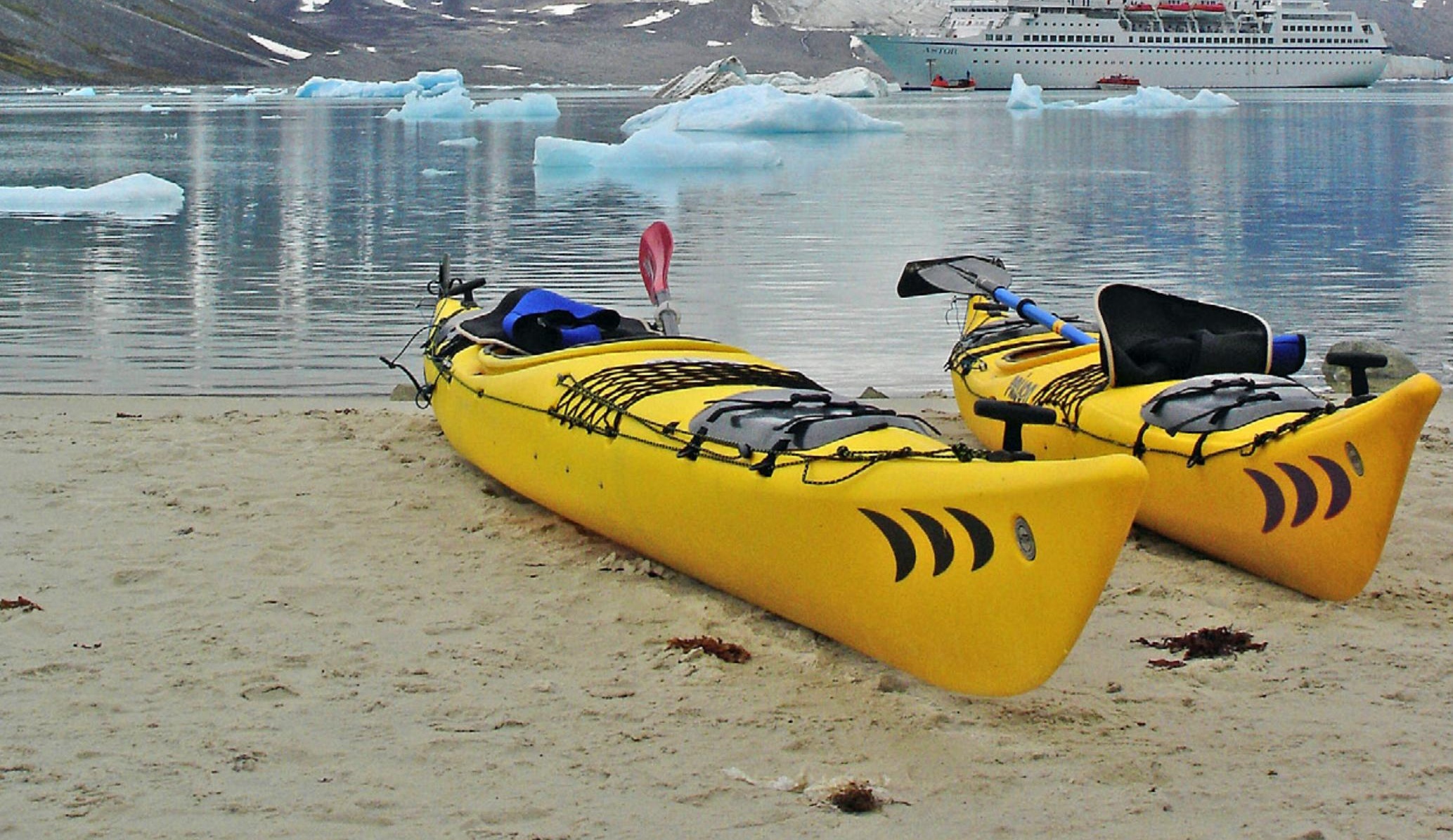




\section{Arctic tourism in times of change: Seasonality}

Outi Rantala, Suzanne de la Barre, Brynhild Granås,

Gunnar Pór Jóhannesson, Dieter K. Müller, Jarkko Saarinen,

Kaarina Tervo-Kankare, Patrick T. Maher and Maaria Niskala

TemaNord 2019:528 


\section{Arctic tourism in times of change: Seasonality}

Outi Rantala, Suzanne de la Barre, Brynhild Granås, Gunnar pór Jóhannesson, Dieter K. Müller, Jarkko Saarinen, Kaarina Tervo-Kankare, Patrick T. Maher and Maaria Niskala

ISBN 978-92-893-6154-5 (PRINT)

ISBN 978-92-893-6155-2 (PDF)

ISBN 978-92-893-6156-9 (EPUB)

http://dx.doi.org/10.6027/TN2019-528

TemaNord 2019:528

ISSN $0908-6692$

Standard: PDF/UA-1

ISO 14289-1

(c) Nordic Council of Ministers 2019

Cover photo: Ritzau Scanpix

\section{Disclaimer}

This publication was funded by the Nordic Council of Ministers. However, the content does not necessarily reflect the Nordic Council of Ministers' views, opinions, attitudes or recommendations.

\section{Rights and permissions}

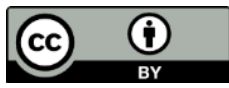

This work is made available under the Creative Commons Attribution 4.0 International license (CC BY 4.0) https://creativecommons.org/licenses/by/4.0

Translations: If you translate this work, please include the following disclaimer: This translation was not produced by the Nordic Council of Ministers and should not be construed as official. The Nordic Council of Ministers cannot be held responsible for the translation or any errors in it.

Adaptations: If you adapt this work, please include the following disclaimer along with the attribution: This is an adaptation of an original work funded by the Nordic Council of Ministers. Responsibility for the views and opinions expressed in the adaptation rests solely with its author(s). The views and opinions in this adaptation have not been approved by the Nordic Council of Ministers.

Third-party content: The Nordic Council of Ministers does not necessarily own every single part of this work. The Nordic Council of Ministers cannot, therefore, guarantee that the reuse of third-party content does not infringe the copyright of the third party. If you wish to reuse any third-party content, you bear the risks associated with any such rights violations. You are responsible for determining whether there is a need to obtain permission for the use of third-party content, and if so, for obtaining the relevant permission from the copyright holder. Examples of third-party content may include, but are not limited to, tables, figures or images. 
Photo rights (further permission required for reuse):

Any queries regarding rights and licences should be addressed to:

Nordic Council of Ministers/Publication Unit

Ved Stranden 18

DK-1061 Copenhagen K

Denmark

Phone +4533960200

pub@norden.org

\section{Nordic co-operation}

Nordic co-operation is one of the world's most extensive forms of regional collaboration, involving Denmark, Finland, Iceland, Norway, Sweden, and the Faroe Islands, Greenland and Åland.

Nordic co-operation has firm traditions in politics, economics and culture and plays an important role in European and international forums. The Nordic community strives for a strong Nordic Region in a strong Europe.

Nordic co-operation promotes regional interests and values in a global world. The values shared by the Nordic countries help make the region one of the most innovative and competitive in the world.

\section{The Nordic Council of Ministers}

Nordens Hus

Ved Stranden 18

DK-1061 Copenhagen K, Denmark

Tel.: +453396 o200

www.norden.org

Download Nordic publications at www.norden.org/nordpub 



\section{Content}

Preface

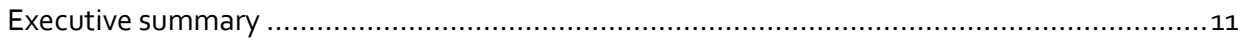

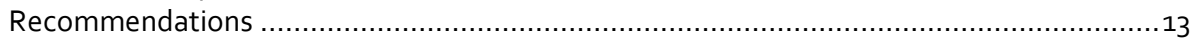

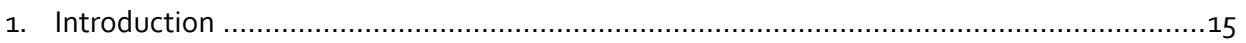

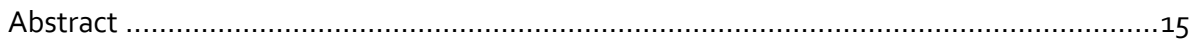

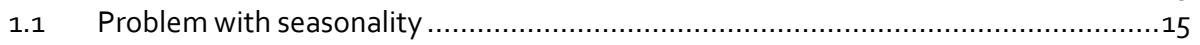

1.2 Brief description of seasons in Arctic Europe and Canada .................................. 19

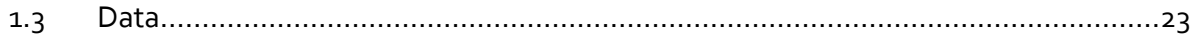

1.4 Potential and restrictions related to developing year-round tourism .................... 25

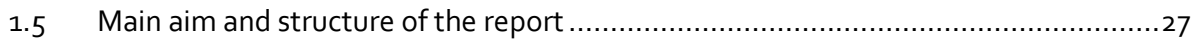

2. Local community perspectives on seasonality ........................................................ 29

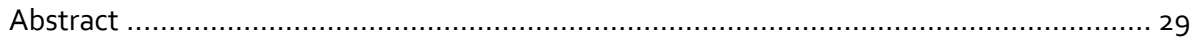

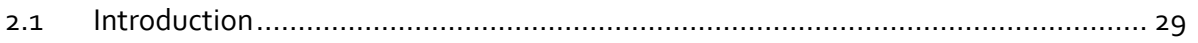

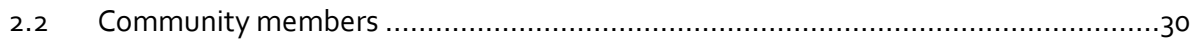

2.3 Small and medium tourism entrepreneurs (SMEs) ......................................... 31

$2.4 \quad$ Business and corporate tourism leaders ..................................................... 32

2.5 Destination management organizations and the public sector............................ 33

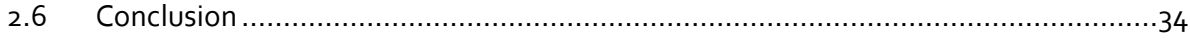

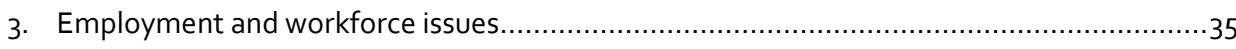

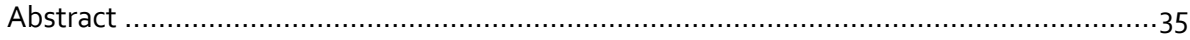

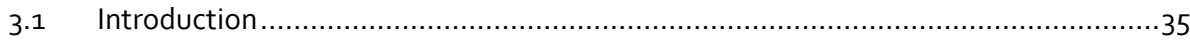

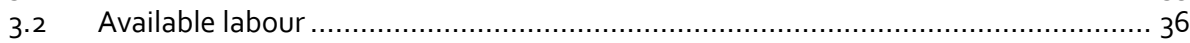

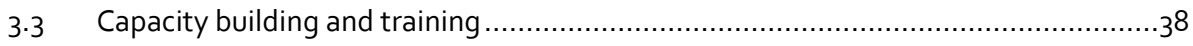

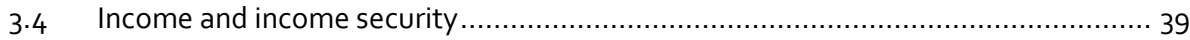

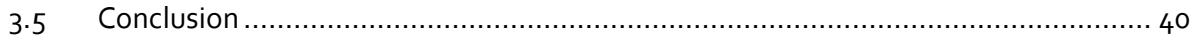

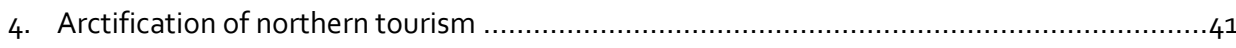

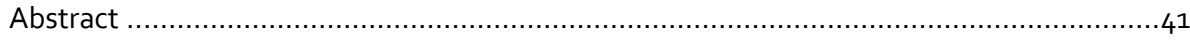

4.1 The image of the North and the Arctic...................................................... 41

4.2 A review of tourism practices and products in the North ................................ 42

4.3 Arctification and its unintended consequences ............................................. 47

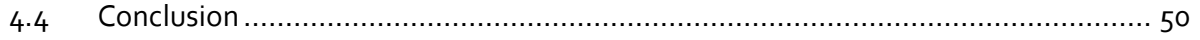

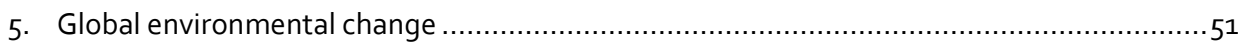

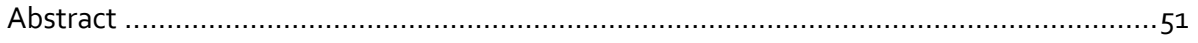

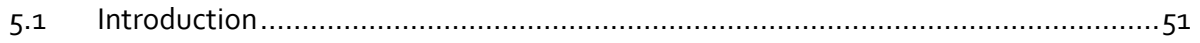

5.2 Seasons will change - what are the implications for seasonality? ........................ 52

5.3 Will climate change affect tourist behaviour? ............................................... 55

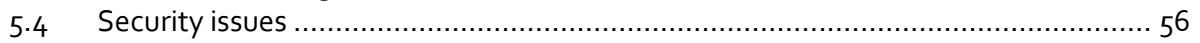

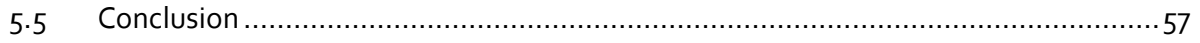

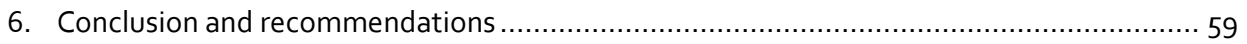

6.1 Challenges and advantages related to seasonality of Arctic tourism ....................59

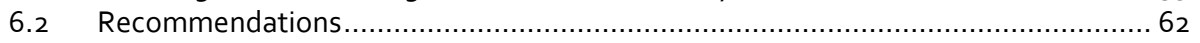

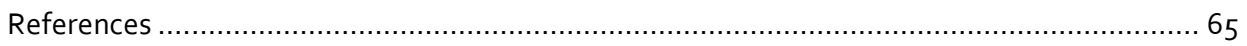

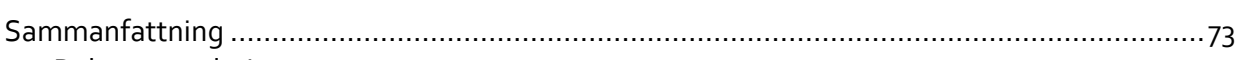

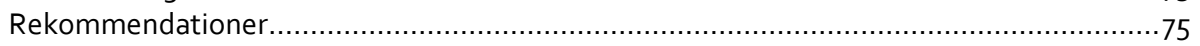




\section{Preface}

The Arctic has become an increasingly popular tourism destination. The increased interest in tourism in the Arctic has resulted in the building of relevant infrastructure and influenced the region, and the people inhabiting it. It has also had an impact on the cultural identity and traditional livelihoods of the region. In particular, the recent rapid growth of tourism, and activities associated with it, will have permanent impacts on the Arctic environment and cultures. In order to address the challenges related to sustainable and constructive development of tourism in the Arctic region, a three-yearlong project, Partnership for Sustainability: Arctic Tourism in Times of Change, was initiated in 2018. The project addresses the following key challenges identified by the steering group of the University of the Arctic's Thematic Network on Northern Tourism: 1) the seasonality of Arctic tourism; 2) urban tourism in the Arctic; and 3) overtourism in the Arctic. The project involves various actors discussing common and place-specific challenges and solutions. The report at hand examines the first key challenge related to the sustainable development of tourism in the Arctic region - seasonality. The data for the report have been produced in collaboration between researchers, students, the tourism industry and the public sector, and further analysed by an international research team, led by the University of Lapland during the first project year. Through the attendance of local Finnish tourism actors and public sector representatives at the collaborative workshops arranged in Rovaniemi, Finland, during the period 29 October -2 November 2018, the viewpoints on issues of seasonality have been influenced by perspectives and experiences from Finnish Lapland. Simultaneously, the international research group has balanced the examination of seasonality by bringing in perspectives and experiences from regions in Arctic Europe and Canada.

The report has been peer-reviewed both internally by the steering group and externally by experts from two Finnish inter-ministerial working groups.

25 March 2019

Outi Rantala

Rovaniemi, Lapland 


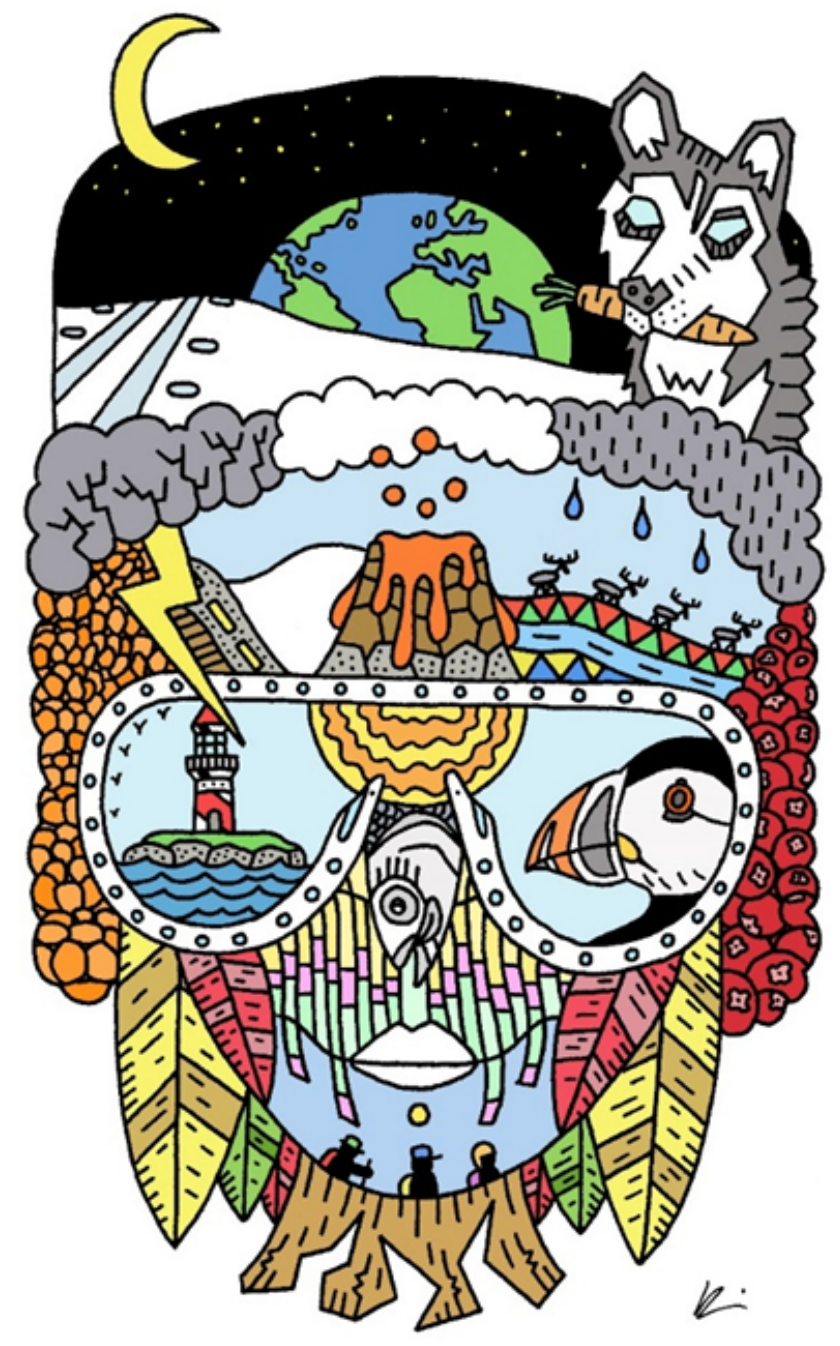


A portrait of the future of Arctic tourism - Artistic statement.

What would the Arctic tourism be like in northern Sweden, Finland, Norway and Iceland in the 2030s?

Bullet trains running on solar energy. Vegetarian dogs. Transitional weather. Sun, silence, snow and darkness. Authentic vs appropriation.

Frilufstliv. Global issues. Extreme weather conditions. Longer stays at slower pace.

Year-round jobs.

All these visions and topics bring us to the most important theme. The respect of nature. The fact that resources are restricted and limited will bring even more demand for environmental education and awareness in the future.

The image of nature is an image of a human.

Kai-Jorma Lompolojärvi. 


\section{Executive summary}

The seasonal nature of tourism is undergoing considerable change across the northern polar region, and is increasingly garnering the attention of tourism destination planners and economic development strategists at all levels, tour operators and the diverse businesses that significantly depend on tourism, and the host communities and residents who negotiate tourism's potential to have both positive and negative impacts. There are four main perspectives from which tourism seasonality can be perceived as a problem in the Arctic. First, from the point of view of the communities, seasonality is problematized when it leads to burnout among local people; when the requirements of a capitalist economy logic contradict the rhythms of lifestyle entrepreneurs; when communities and environments need to encounter the pressures of peak season; and when outmigration and closed facilities and services interrupt - or enhance - the sense of place that settles in during the low season. Second, from the perspective of the workforce and employment, seasonality negatively impacts on the image of tourism as a sector that can offer rewarding long-term jobs and strengthens the image of tourism employment as precarious and low-skilled. Seasonality hinders hiring people with higher-level skills and capacities, and attracts transient workers often characterized by a lack of commitment to place, or at least to a specific employer in a place. In turn, retention issues lead to the high costs associated with the persistent need to train new employees. Seasonality can determine the type and amount of investments made in places by government and municipalities - for example, in the form of housing. Third, there are global processes that alter the problems related to seasonality, such as "Arctification", which reinforces how the visitor imagines the Arctic as a cold and snowy destination, implies a neglect of the distinct environmental seasons of the North, and hinders developing community-based cultural and creative tourism. Finally, a fourth perspective relates to the estimated effects of global environmental change, which are likely to deepen the seasonality aspects of tourism in the Arctic and alter the course of an already sensitive region, along with its capacity for building resilience.

Alongside problem-oriented perspectives, seasonality can also be defined in positive terms: for example, the advantages of shaping narratives and experiences that rely on the attractiveness of having distinct Arctic seasons. Accordingly, the annual life cycles and rhythms of places, communities and environments form the basis for smallsized, lifestyle and indigenous entrepreneurs, and for them, tourism seasonality can be a necessity. Seasonality also enables local communities "to take a break" from tourists and from the impact that tourists have on the community sense of place during the high season. Furthermore, seasonality can be seen in positive terms when it enables moving and travelling around for the seasonal work that currently characterizes much of the tourism employment on offer. The mobile nature of tourism work attracts transient 
younger people to fulfil their needs in the versatile and temporary adventures offered in the Arctic's peripheral areas. Thus, and inadvertently perhaps, the tourism sector is also an unacknowledged training ground for skills development and knowledge building in customer service for a number of other seasonality-oriented employment sectors (e.g., mining, forestry, road construction).

The development of year-round tourism can lead to substantial growth of tourism. The key challenges surfacing along with a substantial growth relate to handling the pressures of the peak season, which local communities and environments will need to face. If the peak season is too strong, the communities will not wish to have year-round tourism, even though the aim would be to balance the seasonality in the long run. In addition, growth of tourism into new seasons may prevent local actors from adapting to revised community rhythms and altered annual place cycles (e.g., impinge on events meant for community building and not for visitors, which occur during months when there is little or no tourism). Furthermore, the sociocultural and ecological impacts of year-round tourism need to be estimated in each specific region, because of the diversity of the Arctic area. Hence, the needs of each specific community should be taken into account by applying "community-first" planning approaches. The key opportunities associated with the substantial growth relate to the possibility of offering year-round and higher-quality tourism sector-related employment, and thus strengthen communities. In addition, the development of year-round tourism can help locally owned medium-sized and larger companies to compete with externally owned companies, thereby preventing the transfer of industry ownership from local stakeholders to international investors - and prevent situations that entail competition through lower price levels. Furthermore, year-round tourism can bring resources to address environmental issues and to enhance the quality of infrastructure.

Overall, year-round tourism in the context of Arctic Europe in the future could consist of approximately 9-10 months of profitable business, which would still leave space for a "recovery season". However, through engaging communities in tourism development and through caring for the environment, and by recognizing the specific characteristics of local contexts and global processes, a sustainable form of tourism could be developed within which a recovery season might not be needed.

To summarize, in order to develop a thriving and sustainable tourism sector in Arctic Europe, the following considerations should be addressed: adopting communityfirst planning; enhancing local business and tourism resources ownership - including sociocultural-oriented resources, for instance festivals or indigenous culture-based attractions, and the utilization of new local innovative integrations of nature and culture in tourism; labour and employment issues; creating strategies to reduce labour precarity associated with tourism; educating travellers about sustainable Arctic ways of living, which are also responsible for how lifestyle entrepreneurship is expressed in the Arctic; enhancing urban Arctic tourism opportunities; utilization of the diverse distinct seasons existing in the Arctic; recognizing global environmental change; and committing to sustainable transportation. 


\section{Recommendations}

- Approach seasonality from a local community perspective, as long-term sustainable development of Arctic tourism relies on engaging in community development and caring for local environments. More specifically, this approach implies that:

- The framework for dealing with seasonality in management and policymaking at regional and national levels should consider contextually specific situations where year-round tourism may constitute a problem and/or an opportunity;

- Spatially sensitive strategies should be augmented with a view to increasing tourism in communities that are peripheral to core areas in the periphery and their tourism (e.g. peripheral to Reykjavik, Iceland).

- Strengthen the image and appreciation of tourism as an economic activity and provider of valuable and fairly compensated employment (SDG no. 8). This could also support positively integrating tourism into the social fabric of Arctic communities. Specifically, this strategy would also:

- Clarify the different career paths that exist within tourism (e.g., service, economic and/or community planning and development, destination promotion);

- Increase and promote the value and status of tourism-related employment (e.g., create strategies and campaigns that challenge the embedded definitions of tourism employment as "entry-level low-paying positions");

- Create ways to celebrate the fact that many young people make their way through university while gaining lifelong and transferable professionalism and other skills while working in this sector;

- Enhance training, education and mentorship opportunities;

- Focus on raising the competencies in the "local" labour pool;

- Work with stakeholders in fighting cheap labour use (social dumping) and labour precarity in tourism.

- Establish and implement regulatory and legislative frameworks that reflect and support mobile and dynamic tourism economies, which would in turn strengthen the destination communities (i.e. where tourism takes place):

- Create support systems for small and micro/nano-sized tourism companies for raising the level of competitiveness (innovation). It is important to recognize the different needs and possibilities of companies in tourism and therefore flexible support is crucial;

- Create nationwide tourism policy initiatives that recognize regional differences and the diversity of companies within the sector;

- Introduce a mechanism to ensure that income tax paid by seasonal workers stays within the community where they are working. 
- Balance the demand in the high seasons with increased efforts to develop products during emerging seasons. This could also help stabilize access to the labour force:

- Improve the knowledge content and service aspects of nature- and culturebased activities;

- Create tourism offerings during other seasons;

- Promote other seasons to high-season tourists.

- Develop high-season tourism based on the local community perspective and with diverse images representing a variety of Arctic meanings and experiences:

- Avoid stereotypical production and marketing of winter tourism that reinforces the Arctification process and the image of the Arctic as cold, snowy and empty of people;

- Support development of new local innovative integrations of nature and culture and development of tourism based on these.

- Develop adaptive capacity and proactive resilience-oriented measures that will positively influence environmental change:

- Improve awareness of global change and its local consequences in Arctic tourism destinations;

- Alongside tourism season diversification, diversify markets and tourism experiences.

- Develop sustainable governance models in Arctic tourism destination development:

- Strengthen the connections made between sustainable governance initiatives and discussions as they are occurring in the Arctic with tourism development processes, including pan-circumpolar and East to West network building, and knowledge creation and sharing;

- Utilize sustainable and responsible tourism initiatives within the framework of the United Nations Sustainable Development Goals (SDGs);

- Broaden the knowledge base and research produced and utilized for developing tourism-related innovations. 


\title{
1. Introduction
}

\begin{abstract}
This chapter introduces the issue of seasonality with a brief literature review and a description of the seasons in Arctic Europe and Canada. The approach to seasonality used in the report as well as the data and methods are then described. In the chapter, potential and restrictions related to developing year-round tourism are discussed with reference to data from the Visit Arctic Europe project.
\end{abstract}

\subsection{Problem with seasonality}

In a workshop arranged in autumn 2017 by an industry-led project titled Visit Arctic Europe (VAE) for tourism actors from Finland, Norway and Sweden, the development of tourism in a new season - autumn - was discussed. The need for a new season was emphasized in order to enable year-round employment and to compensate for overcrowding during the existing high-tourism seasons. Tourism entrepreneurs from the area and destination management organization (DMO) representatives - together with tour operators working with sustainable tourism markets - considered the autumn season to be fresh and full of potential. It was seen to hold a rhythm that was not present in the other tourism seasons in Arctic Europe - a rhythm that arises out of the interconnectedness of the seasonal changes happening in nature and the changes taking place in culture (see also Kyyrä \& Rantala, 2016; Rantala \& Valtonen, 2014). The responsible use of natural resources, combined with personal service that is based on using local knowledge, was considered to be essential - especially since participation, learning and storytelling were seen as central qualities related to the new tourism season.

The development of a new tourism season in northern Finland, Norway and Sweden resembles activities and initiations taking place currently in different locations across the Arctic - due to the insecure weather conditions resulting from climate change, the overcrowding during peak seasons, and the increased importance of tourism as a source of income and economic diversification in peripheral areas. The present report aims to examine seasonality as a key challenge in Arctic tourism development, but one that has the potential to contribute to substantial tourism growth in this vast region. The activities leading to this report brought together researchers, graduate and postgraduate students, local tourism actors and policymakers with the aim of collaborating and creating a framework that coordinates procedures related to developing seasonality. In order to answer our main task - to understand in what contexts and from what perspectives the seasonality of tourism is problematized and interpreted as a problem (or opportunity) in the North - this report 
includes perspectives of communities, small and large companies, municipalities, tourism workers and a fragile polar nature. ${ }^{1}$

Issues related to seasonality and the aim to either extend the existing seasons or to reduce the impact of seasonality have been discussed already for several decades in the circumpolar north. In their 1999 study, Baum and Hagen pointed out that the most common strategy for dealing with the issues of seasonality was to extend the existing tourism season into shoulder periods at either end of the main demand period by using the same resources as those operationalized during the main tourism season, but possibly by targeting alternative markets. In rare cases destinations aspired to overcome issues of seasonality entirely. In addition, they pointed out that even though issues of seasonality are generally seen in negative terms in the context of tourism, the low season allows host communities a period of rejuvenation before the beginning of a new high season. Baum and Hagen concentrated particularly in their study on how northern tourism destinations (in the British Isles, Scandinavia and Canada) responded to seasonality. They identified four initiatives to counter seasonality: the development of events and festivals; market diversification; product diversification; and structural and environmental responses - such as public sector incentives to maintain services and access to facilities, alterations in the labour market environment, structural changes to school holidays and the exchange of seasonal workforces between destinations.

Although seasonality has been in the focus of researchers, regional development activities and industry initiatives, issues of seasonality are still seen to influence, in particular, less diversified tourism contexts, such as nature-based peripheral destinations, more than urban destinations. The problems of seasonality in peripheral destinations relate to the physical and social structures that are designed in accordance with the peak season and which are not used or are underused during the rest of the year. Peak seasons also place a burden on the water supply and waste management systems in peripheral areas (Uusitalo, Tuulentie, Kantola, Huhta, \& Nivala, 2018). Local people face seasonal unemployment and enormous alterations in the size of the population (Uusitalo et al., 2018). Furthermore, the seasonal nature of employment makes tourism work unattractive for many. Nonetheless, there is no consensus across all stakeholders that increased activity across seasons, and the often-cited goal of establishing "year-round" tourism, is desirable. In addition, tourists travel to these areas to encounter peaceful and pure nature, and therefore overcrowding during the peak season may significantly affect the quality of the destinations. DMOs and other tourism planning agents will need to consider how for example lifestyle entrepreneurs see themselves as able to and/or willing to extend their tourism activities into new seasons.

In recent tourism research, seasonality has been examined in particular in relation to climate change (e.g., Amelung, Nicholls, \& Viner, 2007; Gössling, Scott, Hall, Ceron, \& Dubois, 2012; Tervo, 2008). For example, a possible need to schedule holidays

\footnotetext{
${ }^{1}$ Fragile nature is affected by tourism differently during different seasons, and this needs to be addressed when developing seasons. However, there are environmental issues related to the development of nature-based tourism in Nordic countries, such as issues related to everyman's rights, that are not addressed here, but have been discussed in the previous report, "Tourism, nature and sustainability", published in 2018 in the TemaNord series.
} 
differently in the future due to climate change and unsecure snow conditions, in the context of Christmas tourism, has been pointed out (Tervo-Kankare, Hall, \& Saarinen, 2013). Furthermore, recent research projects, such as "New Turns in Winter Tourism" led by the UiT - the Arctic University of Norway - and financed by the Norwegian Research Council, have studied both events (such as the international dog-sled competition Finnmarksløpet - see Granås, 2018; Jæger \& Olsen, 2016) and the development of activities as ways of dealing with seasonal tourism. The research on activities in the project included the expansion of Northern Lights tourism and the softening of adventure tourism and how these developments influence the organization of winter tourism in Arctic Europe (e.g., Heimtun, Jóhannesson, \& Tuulentie, 2014; Heimtun \& Viken, 2015; Jóhannesson \& Lund, 2017; Rantala, Hallikainen, Ilola, \& Tuulentie, 2018). Recent research results from Arctic Europe have also discussed the possibility of concentrating, instead of on summer or winter products, on the development of well-being tourism (Kyyrä \& Rantala, 2016; Uusitalo et al., 2018), and the possibility of highlighting the seasonal variation of Arctic rhythms - such as different lightscapes and soundscapes - rather than reducing the influence of season (Rantala \& Valtonen, 2014). In addition, it has been pointed out that the seasonal rhythms affect the place attachment of seasonal tourism workers (Tuulentie \& Heimtun, 2014).

There are also studies discussing whether year-round tourism should be achieved by concentrating on the development of airports and enhancing the accessibility of international scheduled carriers. According to Halpern (2008), low-cost carriers have encouraged the development of new markets that are based on independent and flexible travel arrangements, which are likely to satisfy tourists that visit, for example, Lapland outside of winter. However, those example initiatives will not satisfy tourists who seek packaged (winter) holidays. Halpern (2008) sees the development of international tourism via domestic services as the easiest way of securing year-round growth but points out that the inconvenience and added cost involved in travelling via domestic hub airports cannot act as a replacement for the international charter carriers. The direct international charter flights provided by Lufthansa, Germania, Monarch, Norwegian Air and Finnair enabled the increase of tourism in Finnish Lapland during the period 2016-2018 (House of Lapland, 2018). Similarly, in Kuusamo, Finland, the success of the town's tourism development has been enabled by the Gateway to Kuusamo Lapland project, which has resulted in the growth of, mainly, wintertime tourism through increased flight connections.

A report published in 2017 by the Prime Minister's Office in Finland (Konu et al., 2017) lists several examples of best practices to deal with the issues of seasonality. These include:

1. the case of the ski centre in Hemsedal in Norway, where summer tourism was developed by concentrating on improving the quality of the services (see Engeset et al., 2016); 
2. the case of Voss in Norway - Voss has been able to change from being a winter tourism destination to a year-round tourism destination by developing adventure tourism;

3. the development of summer activities in Levi (Finland);

4. the development of congress tourism at the Haltia Nature Centre (Espoo, Finland);

5. several cases related to the development of well-being tourism; and

6. the opening of an art museum presenting indigenous art in Whistler (British Columbia, Canada).

The above list could be completed with many good examples, such as the springtime culinary tourism in the Yukon territory (Canada), which complements and supports nature-based seasonal events, such as the return of migratory birds; also for Yukon there are emerging invitations to witness the "fall colours" - which for a long time have been the cornerstone of developing an autumn visitor season in southern Canada (e.g., southern Ontario, Quebec and Cape Breton). Finally, there is the noteworthy development of Northern Lights tourism across the Nordic countries and Canada.

Despite the research information and reports available, issues of seasonality remain among the core issues in the development of tourism in Arctic and peripheral areas. For example, in the current creation of the new tourism strategy for Finnish Lapland, year-round tourism has been brought up again (Regional Council of Lapland, 2019). It is also a focal point in the most recent tourism strategy paper produced by Icelandic authorities (Atvinnuvega- og nýsköpunarráđuneytið, 2015). In their strategy from 2018, the DMO of Northern Norway, Visit Northern Norway, still presents the goal of developing year-round sustainable tourism as their core assignment (Visit Northern Norway, 2018). In Canada, seasonality discussions and strategies for creating yearround tourism are also in place in two of the three northern territories, Yukon and Northwest Territories (NWT, 2016, 2018; Yukon Government, 2017, 2018). Only a cursory mention of the opportunities available through expanding the season or markets for its current destinations and activities is offered in Nunavut (Government of Nunavut, 2012). Arguably, the least accessible Canadian destination located in the nation's eastern Arctic territory is still developing its very short two-month or so summer tourism, which is largely based on marine cruise and yacht tourism.

In the report at hand, we concentrate on Arctic Europe - referring to northern Finland, Norway, Sweden and Iceland. The northern polar region is vast and has many distinguishing features across regions and nations. Like many Arctic phenomena, the differences and similarities that make up Arctic tourism across international boundaries offer compelling insights into these areas. To capture an enhanced and more comprehensive examination of pan-Arctic tourism phenomena, we have also included a Canadian perspective in our report. Seasonality in tourism follows certain similar trajectories across the Arctic areas included in this report, and extending tourism seasons is a collectively held objective shared across them. However, the differences can be just as informative. Winter tourism is relatively new in the northern Canadian context and has 
attracted limited attention until recently. Summer tourism has dominated the visitor sector in Canada's north. To the extent that winter tourism has been a force attracting attention in Arctic Europe for a longer period of time, and to the extent that summer visitations in Arctic Europe may differ from Canadian summer visitations in terms of markets, and possibly activities - predominantly still nature-based, but increasingly complemented by culture-based offerings, both indigenous and settler cultures - there is much to be gained by pointing out comparative perspectives where possible.

The seasonality of Arctic tourism is, in different ways, pivotal to the development of sustainable Arctic societies, in which tourism development, based on regional resources, is balanced with the development of inclusive and democratic places for people living in the Arctic. Hence, this report aims to tackle issues of seasonality comprehensively.

\subsection{Brief description of seasons in Arctic Europe and Canada}

Tourism seasons and issues related to seasonality differ among regions across Arctic Europe, and within specific areas (e.g., different destinations within Finnish Lapland). Therefore, a short introduction to seasonality across Arctic Europe and Canada is provided here. The description of seasons is based on data produced as part of an international workshop arranged in Rovaniemi in 2018 (see Section 1.3).

\subsubsection{Seasonality in Iceland}

Iceland has experienced a rapid increase in tourist arrivals in recent years. Traditionally the three summer months of June, July and August have been the high season. This is still the case, although the recent growth in tourist arrivals has proportionally been greater during the winter season. This is in tandem with a long-term emphasis by tourism stakeholders and authorities on extending the shoulder season and bolstering Iceland as a whole-year destination (Jóhannesson, Huijbens, \& Sharpley, 2010). Hence, there has been a slight evening out of the seasonal differences in tourist arrivals. In 2017, the traditional low-season months had a combined share of approximately $64 \%$ of all international tourist arrivals compared to $50 \%$ in 2010 (Árnason \& Welling, forthcoming). In 2017, roughly $35 \%$ of international tourist arrivals were in the three summer months compared to $40 \%$ in 2015 . The spring is the smallest season, with approximately $13 \%$ of the total number of tourist arrivals in 2017 (Ferðamálastofa Íslands, 2018).

It is interesting to note a stark regional difference in seasonality. Information on guest nights by region show that there is hardly any winter tourism outside the capital region and the south coast region. This is mainly due to the fact that Keflavík International Airport is almost the only gateway into the country. During wintertime, when weather is harsher and holiday durations are on average shorter, visitors tend to travel shorter distances away from the capital area. Without some major changes in accessibility or length of stay, this is unlikely to change in the near future. 


\subsubsection{Seasonality in northern Finland}

In Finnish Lapland, tourism has been a key development sector since the beginning of the 1980s. The growth of the tourism industry has been based on the winter season and related recreational services in international tourism demand. In 2017, approximately 2.9 million tourists visited Lapland, of whom about 1.5 million were foreign tourists (House of Lapland, 2018), and the number of registered overnight stays has more than doubled from 1.25 million in 1990. However, the actual number of tourists is estimated to be three times more than the registered number, as approximately two-thirds of the overnight stays are non-registered, at least in some resorts (Regional Council of Lapland, 2015; see also Satokangas \& Vieru, 2017). The international tourists are mainly from Great Britain, Russia, Germany and Japan.

The Christmas season and winter continue to be the largest draws to Lapland, with the month of December being the most popular, both in terms of overnight stays and passenger traffic. The lowest number of overnight stays in 2017 was in May, with 63,000, whereas in December there were 465,000 overnight stays registered (see Figure 1). The months from January to April form the second peak season after Christmas tourism, and the summer and autumn months from June to September the third season.

Figure 1: Registered overnight stays in Lapland in 2017

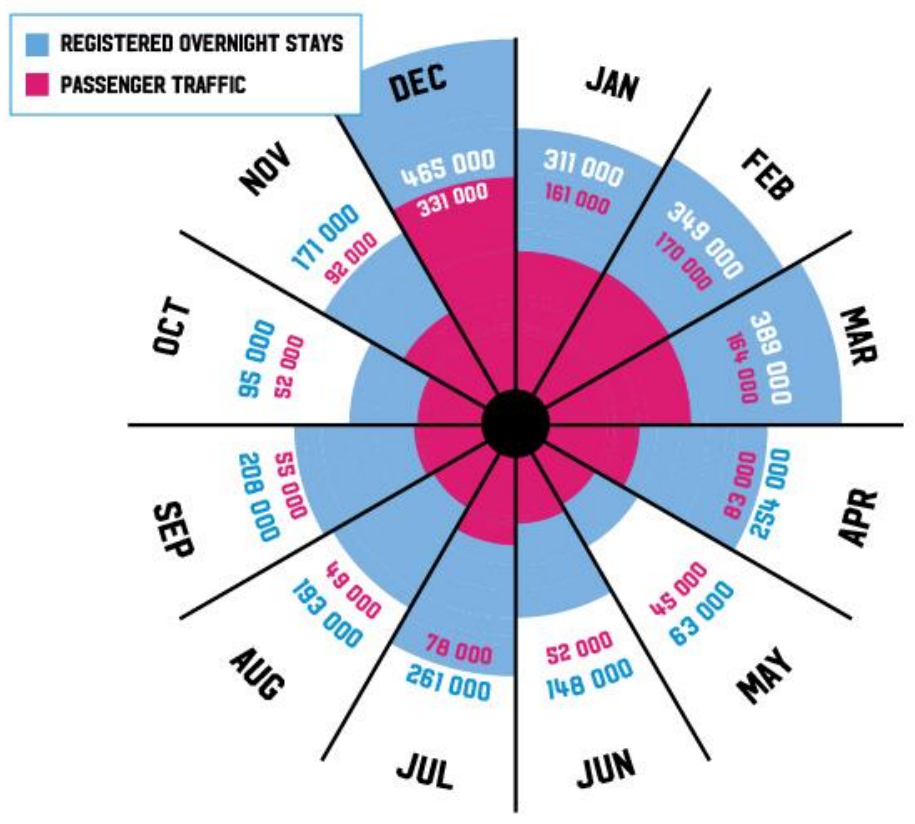

Source: House of Lapland, 2018.

Year-round tourism has been a target of tourism development in northern Finland for a long time, and different procedures and projects have been undertaken in order to develop summer tourism in skiing, i.e. winter tourism destinations. In Lapland, the current tourism strategy states that increasing summer tourism cannot be based in 
future on specific single actions but will result from long-term persistent common work (Regional Council of Lapland, 2015; see also Uusitalo et al., 2018). Hence, in the ongoing creation of a new tourism strategy the development of summer tourism is again brought up as one of the focuses.

There are also specific destinations within northern Finland where summer tourism forms the main season. These destinations include fishing tourism destinations, like the Tornio and Teno rivers. In addition, in many destinations located close to a national park (e.g., destination Enontekiö close to Pallas-Yllästunturi National Park, destination Kuusamo close to Oulanka National Park, and destination Suomussalmi close to Hossa National Park), the numbers of summer visitors and overnight stays reach high levels.

\subsubsection{Seasonality in northern Norway}

Like other Nordic regions, northern Norway has experienced an increase in tourist arrivals in recent years. Much public attention has been paid to the recent growth in winter tourism in the region. This has clearly changed the conditions for the tourism industry and influenced social life in the villages and towns most strongly affected by this increase. Importantly, the summer season is nevertheless still the biggest season for tourism in northern Norway as a whole. From statistics based on registered overnight stays in northern Norway, we see an increase in winter tourism from approximately $1,200,000$ in 2012 to more than $1,500,000$ in 2018 . There were similar numbers for summer tourism, ranging from approximately 1,800,000 in 2012 to more than $2,300,000$ in 2018.

Seen from this macro level, one can discuss whether the growth in winter tourism is strong enough within the total growth frame, considering the strong growth in summer tourism and the desired goal of public authorities to develop all-year-round tourism. However, such discussions have less value when taking into account the geographical distribution of tourist arrivals. Both the tourism growth and the seasonal variations are unevenly distributed among different geographical areas in northern Norway. In total, Nordland County to the south, where the Lofoten Islands are found, has considerably higher tourist numbers than the other two counties of northern Norway, and Finnmark County to the north east is the "little brother" of North Norwegian tourism, with numbers that are less than half of those of Nordland. When differentiating among the three counties of northern Norway, we also see that, in Nordland, the summer season is a peak season. In Troms County, located in the middle of the region, the summer and winter seasons have more equal numbers, but the development from 2012 to 2018 led to higher numbers during winter. In the same period, the growth in winter tourism in Finnmark was limited, and overall, the summer season has increased more than the winter season since 2012.

In terms of geography, northern Norway and its three counties constitute wide geographical areas that together make up $35 \%$ of Norway's mainland. The fact that Finnmark County is a little bigger than Denmark illustrates the same point further. We know that further geographical variations within each county tell of challenges and opportunities regarding seasonality in highly differentiated ways. One example is 
Honningsvåg in Finnmark, which has very high visitor numbers during summer, based on the North Cape and the midnight sun, but very little winter tourism. Adding to the specific geography of northern Norway are the relatively low numbers of inhabitants compared with square kilometres. For example, variations in tourism growth between Nordland and Finnmark must also be seen in relation to the size of the societies involved, with 240,000 inhabitants in Nordland, 160,000 in Tromsø and only 75,000 in Finnmark.

\subsubsection{Seasonality in northern Sweden}

The traditional idea of tourism in northern Sweden is related to the imagination of northern Sweden as wilderness and on the periphery. The roots for such an image are to be found before the 2oth century and the Swedish Tourist Association's (STF) campaign "Känn ditt land" moulded a perception early on that the North should be explored through outdoor recreation and hardship (Sandell \& Sörlin, 2000). One of the early primary aims of the STF was to make the Swedish mountains accessible for tourists by establishing a system of long-distance hiking tracks. Hence, the focus for development historically has been the summer season.

Here the Swedish Arctic is defined as the counties of Västerbotten and Norrbotten, where tourism products are increasingly labelled "Arctic" or contain aspects that are related to features such as snow, ice and the Northern Lights. And indeed, the winter season in particular saw a growth of tourism during the 1990 s and early 2000 . Müller (2011) showed, for example, that seasonal patterns of passenger arrivals at Kiruna Airport changed dramatically in this period. Most likely, because of the immediate success of the Icehotel outside Kiruna, the winter season became the busiest time at the airport. Similarly, the business of car testing in Lapland drew considerable winter traffic to Arvidsjaur Airport too.

Despite this success of winter tourism, the summer season remained dominant in Väster- and Norrbotten counties, where camping provides most guest nights during summer. Overall tourism development in the region has been positive, with growing numbers of overnight stays. This is also true when scrutinizing the monthly changes in the region. December and January were the months that showed the greatest increase between 2008 and 2017 with $57 \%$ and 39\%, respectively. Even during August and September a $37 \%$ increase was registered. However, with the exception of December, where a constant growth of overnight figures can be registered, there are considerable changes between the years, indicating the importance of other factors affecting tourism demand. The available data do not allow it to be discerned where in the region such increases have taken place. Thus, it is somewhat difficult to relate changes to product development or similar factors altering attraction within the region. Statistics indicate, however, that growth, not least in Kiruna but elsewhere too, is because of the growth of global demand rather than increased visitations from the major demand markets within Sweden and the neighbouring countries. This applies in particular to Norrbotten County, where many municipalities register a proportion of foreign guest nights of more than $30 \%$. 


\subsubsection{Seasonality in northern Canada}

It is challenging to make general statements on climate or tourism in the Canadian context given its size and dramatic regional differences. Nonetheless, there are noteworthy trends in tourism seasonality at a national level, and specific regional assessments, which are useful for the present report. In 2017, Canada welcomed 20.8 million visitors, the highest ever in Canadian history, which surpassed by one million the previous record set in 2002. From June to August 2018, Canada welcomed 8.9 million international visitors, which was an increase of $1.8 \%$ from the summer of 2017 (Destination Canada, 2019). The summer season - generally early June to the end of August - remains the predominant tourist season in Canada; however, many jurisdictions envision extending their tourism. Seasonality discussions and strategies aimed at creating year-round tourism are in place in two of the three northern territories, Yukon and Northwest Territories (NWT, 2016, 2018; Yukon Government, 2017, 2018). Nunavut offers only a cursory mention of the opportunities available through expanding the season or markets for its current destinations and activities (Government of Nunavut, 2012). Arguably, Canada's least accessible eastern Arctic territory is still developing its very short two-month or so summer tourism, which is largely based on marine cruise and yacht tourism.

\subsection{Data}

This report is based upon research expertise on Arctic tourism that has been developed over the past decade. Since 2008, the University of the Arctic's Thematic Network on Northern Tourism has worked with multidisciplinary research projects on Arctic tourism. These projects include: 1) Tourist Destination Development: Place Making and Work Performances in Arctic Networking Societies, funded by the Norwegian Ministry of Foreign Affairs between the years 2010 and 2012; 2) WINTER: New Turns in Arctic Winter Tourism, funded by the Norwegian Research Council between the years 2013 and 2016); 3) SIU-funded project Joint Higher Education on Northern Tourism between the years 2015 and 2018 and ongoing joint master's level education and master's degree programme; and 4) the recently formed consortium to work with a tourism industry-led project Visit Arctic Europe (VAE) during the period 2016-2017. The members of the steering group of the thematic network brought their expertise together in order to address key challenges surfacing along with a substantial growth of tourism in the Arctic, and in particular to address the issues of seasonality in Arctic Europe and peripheral and northern Canada.

The expertise of the group was mobilized at an international workshop arranged for 29 October - 2 November 2018, in Rovaniemi, Finland. The workshop included, first, both presentations and discussion of ongoing issues related to seasonality in the respective areas among the researchers. Secondly, the workshop included focus group discussions that brought together the researchers and both graduate and postgraduate students from the respective geographic areas, policymakers, entrepreneurs and DMO representatives, representatives from other research institutes and Metsähallitus (a 
state-owned enterprise that administers state-owned land and water areas in Finland), and representatives from the second Visit Arctic Europe project. Thirdly, a future scenario workshop was organized among the above-mentioned participants during which future scenarios related to the seasonality of tourism in Finnish Lapland, Finnmark, Iceland and northern Sweden were constructed. A local artist from Finnish Lapland was commissioned to visualize the material from the scenario workshop (see "A portrait of the future" on pages 4-5). Fourth, based on the first two workshop days, an open panel discussion, "Disturbing tourism seasons: changing demands, changing expectations", was organized at the Korundi House of Culture in Rovaniemi. The panel discussion was streamed live and shared via various Facebook channels with representatives of both the tourism industry and academia.

All the material produced during the workshop (see Table 1) was organized, transcribed, and analysed by using qualitative research methodologies, such as thematic reading and analytical reading methods. The primary data were supplemented by data collected by the second Visit Arctic Europe project. These data consist of a questionnaire-based survey $(\mathrm{N}=90)$ realized in autumn 2018 among tourism-related enterprises in northern Sweden, Norway and Finland. In addition, the international graduate students who attended the workshop produced travel diaries during their one-week visit to Rovaniemi and the travel diaries have been used to represent off-season tourism experiences in Arctic destinations.

Table 1: Data produced during the workshops arranged in Rovaniemi between 29 October and 2 November 2018

\begin{tabular}{|c|c|}
\hline Data & Reference in the report \\
\hline Regional overviews of seasonality & $\begin{array}{l}\text { Overview Iceland } \\
\text { Overview northern Finland } \\
\text { Overview Finnmark } \\
\text { Overview northern Sweden } \\
\text { Overview Cape Breton } \\
\text { Overview Yukon }\end{array}$ \\
\hline Focus group discussions & $\begin{array}{l}\text { Focus group } 1 \text { - facilitated by Granås and Welling } \\
\text { Focus group } 2 \text {-facilitated by Müller and Tervo-Kankare } \\
\text { Focus group } 3 \text { - facilitated by Rantala and Maher } \\
\text { Focus group } 4 \text { - facilitated by Jóhannesson and de la Barre }\end{array}$ \\
\hline Future scenarios for seasonality in 2030 & $\begin{array}{l}\text { Seasonality in Iceland } 2030 \\
\text { Seasonality in Finnish Lapland } 2030 \\
\text { Seasonality in Finnmark } 2030 \\
\text { Seasonality in northern Sweden } 2030\end{array}$ \\
\hline Visualization of seasonality in Arctic Europe 2030 & A portrait of the future \\
\hline $\begin{array}{l}\text { Panel discussion "Disturbing tourism seasons: changing } \\
\text { demands, changing expectations" }\end{array}$ & Panel discussion \\
\hline $\begin{array}{l}\text { VAE questionnaire: development of seasonal tourism in } \\
\text { Arctic Europe tourism companies }\end{array}$ & VAE questionnaire \\
\hline $\begin{array}{l}\text { Travel diaries representing off-season tourism experiences } \\
\text { in Arctic destinations }\end{array}$ & Travel diary 1-7 \\
\hline
\end{tabular}




\subsection{Potential and restrictions related to developing year-round tourism}

Based on our data and as a background to this report, it should be noted that when discussing issues of seasonality in the Arctic, and considering the development of yearround tourism, the participants from the workshop made it very clear that year-round tourism for them would mean having nine to ten months of profitable business. As one of the participants in focus group discussion 3 articulated:

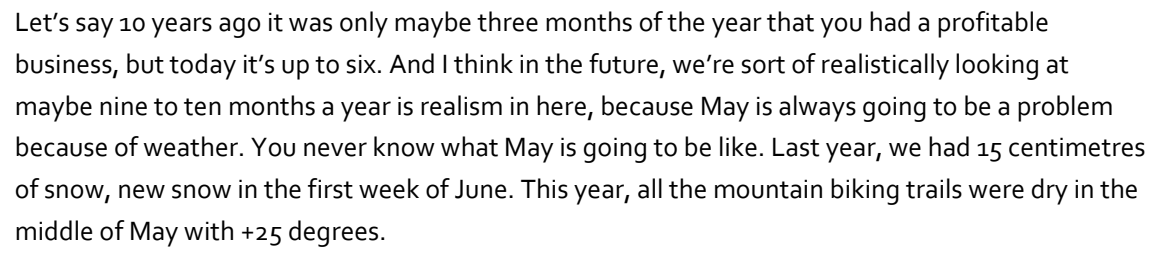

In addition, foreseeing the month of May as being the most problematic, the participants saw strong potential in the development of tourism during the autumn season - especially as a result of the popularity of the Northern Lights. In the following chapters of this report, we will be looking more closely at the issues that relate to developing year-round tourism in Arctic Europe. Since our perspective is on understanding why seasonality creates a problem for communities, the workforce and the environment, the particular months and product development within these months will be given less space in this report. However, as the second VAE project conducted a survey on seasonality among their project participants in 2018, some preliminary results from the survey will be presented here in order to reflect and bring a wider perspective on the topics covered in this report. The results of the survey illustrate well the potential and restrictions that exist for making a profitable tourism business during all 12 months of the year.

Many of the companies that participated in the survey offer their guests outdoor activities; for example, almost two-thirds (59 respondents) of the respondents offer Northern Lights experiences, and about half of them provide snowshoeing (52), food experiences (48), trekking/hiking (47), cross-country skiing (46), dog-sledding (huskies 43), ice fishing (41) and photography tours (40) for their customers.

The companies were asked questions about their current low seasons and where they saw most growth potential (on a scale of 1-6, where $1=$ low growth potential and $6=$ high growth potential). In general, the months of May (74\%), October (79\%) and November (62\%) were referred to as low season by the majority of respondents, but of course, there were regional and activity-related differences. The months with the most growth potential were considered to be September and October, but the differences were not very high - all months were considered to have some growth potential ( $\mathrm{min}$. mean value 3.8 , max. mean value 4.7 on a scale of $1-6$ where $1=$ low growth potential and $6=$ high growth potential). In addition, the companies presented views about the selling points and hindrances for the months they saw as having the most growth potential. Here, the results are presented according to country, but operation-level 
analysis might also bring interesting insights into this topic. In a comparative destination, although one with a strong summer tourism season versus needing to extend the winter season, Cape Breton also saw the most potential in the autumn two decades ago. As a result they designed an autumn music festival (Celtic Colours) to extend the summer season through to mid-October

In Finland, the answers encompassed the area of Finnish Lapland. According to data, the low-tourism seasons in Finland are the springtime and autumn, especially the months of May (all respondents referred to May as low season) and October (24 of the 25 respondents labelled this low season). The months that were not considered to be low season were winter months: from December to March. The respondents were also asked to rank the months of the year by their growth potentiality. In Finland, the months considered to have the most growth potential were those from June to November, with November (5.0) and October (4.9) ranking the highest in terms of potential for growth. The months considered by Finnish respondents to have the least potential in terms of growth were March (2.9) and February (3.1).

The respondents in Norway considered the low season to be during October and November. In comparison, the summer months, from June to August, were not labelled as low season. This is the opposite to Finnish Lapland. Nonetheless, in both countries October was the month that was considered to be low season by the great majority, although in Finland, the respondents were closer to being unanimous. In Norway, most growth potential is seen to take place in September (4.8), October (4.8), January (4.7) and March (4.6). Thus, there seem to be two potential seasons for the most growth potential: winter/spring and autumn. The months of July (3.8) and August (3.9) were considered to have the least growth potential.

The respondents from Sweden were mostly located in northern Sweden. According to the survey, the participants consider the low season in tourism business to be from April to November. May, June and especially October were considered to be low season by the majority of Swedish respondents, while the months from December to March received the fewest rankings as being low season. The responses suggest that the growth potential in Sweden varies to some extent: the most growth potential exists during winter and springtime, January (4.6) and April (4.7), and in the early autumn months from August (4.8) to September (4.9). In general, all the months were considered to have growth potential close to or over 4 . Surprisingly, here, the respondents also see high growth potential in January, which seems to be outside the current low season.

The participants provided several ideas for selling points and/or strengths for the three months with the most growth potential. One of the popular answers referred to the benefits of low-season tourism (7 remarks). During the low season, there are more facilities available for tourists (transportation, accommodation), main attractions are not overcrowded, it is possible to negotiate on the price of services and products, and more tailored services for tourists can be offered. The most often named single selling point was the Northern Lights (8). In addition, authentic and pure nature was mentioned by several respondents (7). Cultural products, local communities and local Sámi (6) culture events were also named as strengths. Other points that were 
mentioned by some of the participants were the midnight sun (4), the mild climate (3), the tranquillity and silence (3), non-polluted air (3), different activities (3), photography tourists (2), the Arctic light (2), well-being activities (2) and the local food (2).

The respondents were also asked to give their opinions on what hinders or restrains the actualization of the growth potential. The answers varied. It seems that accessibility and transportation, including flight connections (23 remarks), are the biggest hindrance to realizing growth. Marketing was considered a hindrance to the actualization of growth potential by 18 respondents. The participants mentioned that marketing often focuses on promoting only a certain season(s). One important aspect brought up by the respondents was the lack of information for tourists (16). In addition, product development (15) was seen as an important issue. The respondents stated, for example, that there were not enough interesting products to attract visitors. Budget and resources ( 9 ) were seen to restrain growth by a tenth of the respondents. A lack of collaboration (7) among different actors and challenges with sales (6) were named several times as well. The participants said that they faced difficulties finding the right channels to reach potential foreign customers. Some also mentioned the challenges with accommodation (5), referring to many accommodation facilities closing their doors after the high season. Participants also mentioned online-selling problems (3), the economic value of keeping businesses open in the low season (3), travellers' preferences (3), finding time (2), infrastructure (2) and weather challenges (2).

\subsection{Main aim and structure of the report}

The main aim of the report is to understand in what contexts and from what perspectives the issue of seasonality in Arctic tourism is discussed and problematized. In an Arctic context, the report thus aims to:

- understand how (the concept of) seasonality is defined and what it means;

- identify key challenges and opportunities surfacing along with a substantial growth of tourism due to developing new seasons (or year-round tourism);

- suggest alternative ways of coping with issues of seasonality with the aim of developing a thriving and sustainable tourism sector.

The report is organized according to the main themes that were identified as a result of the collaborative analysis process: local community perspectives on seasonality; employment and workforce issues; the Arctification of northern tourism; and global environmental change. These four themes form the key issues around which the challenges and opportunities brought up during the workshops can be placed and worked with. Thus, the report is structured next into four chapters, each of which discusses one of the key themes. The discussion in each chapter is based on the analysis of the workshop data, but additional information and expertise related to different regions have been brought in when writing the report. 
The first thematic chapter approaches the issue of seasonality from the perspective of local community - that is, from the perspectives of the residents, companies, destination marketing organizations and the public sector. In the second thematic chapter, employment and workforce issues are discussed in more detail from the perspectives of labour availability, capacity building and income security. Under the third theme, the impact of producing, performing and consuming northern Europe as Arctic is discussed by illustrating the linkages between Arctification and seasonality. In the fourth and final thematic chapter, the implications of global environmental change for seasonality are presented.

The report ends with a concluding chapter in which recommendations based on the discussion and analysis of the four key themes are presented. 


\title{
2. Local community perspectives on seasonality
}

\begin{abstract}
Seasonality needs to be examined from the point of view of the challenges it brings to those impacted by tourism at all levels. There are diverse community-related perspectives to consider, among them: community members (residents), tourism entrepreneurs, including small-scale lifestyle tour operators, larger-scale business and corporate tourism leaders, destination management organizations (DMOs) and the public sector at all levels. The chapter summarizes key issues associated with diverse perspectives involved in tourism and seasonality. Sustainable development of Arctic tourism can be strengthened by building development strategies and plans with longterm perspective that is inherent in engaging in community development and caring for environments. Hence, when working with seasonality, attention should be paid to how tourism intertwines in local environments, is embedded in local communities and enmesh in local economies.
\end{abstract}

\section{$2.1 \quad$ Introduction}

Seasonality is a significant dimension of tourism development in the Arctic, and its influence has profound impacts on communities, including their economic diversification objectives as these relate to the opportunities presented by tourism. For instance, creative tourism, which focuses on co-creation of tourism experiences and on offering visitors opportunities to develop their creative potential through active participation in learning experiences (Richards, 2011), is a promising area of growth in the Arctic regions that has the potential to positively influence expanded seasonality, as well as entrepreneurship opportunities, economic diversification, and community innovation and resilience (Brouder, 2012; de la Barre,in press; Jóhannesson \& Lund, 2018; Nordic Council of Ministers, 2018; Petrov, 2016; Petrov \& Cavin, 2017; Viken, Granås, \& Nyseth, 2008). Creative tourism can complement a destination's naturebased activities on offer; moreover, it has the potential to expand markets (soft adventure visitors) and attract new markets (cultural tourists interested in arts and culture-based tourism).

However, seasonality must also be considered for the challenges it brings to those impacted by tourism at all levels. There are diverse community-related perspectives to consider, among them: community members (residents), tourism entrepreneurs, including small-scale lifestyle tour operators, larger-scale business and corporate 
tourism leaders, destination management organizations (DMOs) and the public sector at all levels. Visitor perspectives also play a significant role in the development of seasonality, and how these are considered plays a pivotal role for communities, primarily in terms of how they are represented and the expectations they may arrive with. The following sections summarize some key issues associated with diverse perspectives involved in tourism and seasonality.

\subsection{Community members}

Tourism in the Arctic relies on the goodwill, interest and engagement of the residents who live in the small communities that characterize this region. At the heart of any issues surrounding seasonality is the way tourism is embedded in the community, and how inhabitants live with peak season-based tourism versus all-year-round tourism. In order to achieve long-term sustainable tourism development it needs to be examined how seasonality how seasonality versus all-year-round tourism may work in particular community contexts: to what extent do local residents want to "enjoy and endure" the peak season, and then "take a break" from the tourists and the impact they have on the community's "sense of place" for the rest of the year? A similarly formulated question may arrive at different answers: if the peak season is unbearable and unbalanced, then does it make sense from a community perspective to spread tourism throughout the year and develop tourism in a long-term perspective as year-round?

Given the continuing significance of "authenticity" (MacCannell, 1976) as a central feature of the tourism experience, the experiential attributes associated with seasonality at community levels must be identified and addressed. For example, tourism in small places relies a lot on the community life at local levels. Community life at local levels often occurs primarily for residents first, for instance its festivals and events such as music and cultural festivals, arts and theatre events. These communityoriented activities in turn depend on social capital in the form of volunteers, sponsorships and collaborations, and increasingly form part of "shared" and "circular" economies, deeply embedded in the social and cultural capital of a place. Tourism economies are known to rely on commodification to different degrees, and small communities are at risk of volunteer and sponsor "burnout" when it comes to their resident-based events, let alone when these are enhanced to provide "entertainment" or values-based experiences to visitors. These types of concerns intersect with assessments of development approaches that compare community benefits from tourism resulting from "community-first" planning approaches (which employ tourism as a resource to benefit communities) versus "tourism-first" planning approaches (which aim to use communities as resources to grow tourism) (see, for instance, Mair \& Reid, 2007). 


\subsection{Small and medium tourism entrepreneurs (SMEs)}

Arguably, the backbone of Arctic tourism is made up by the many small companies that offer experiences and services for visitors. These small companies - or SMEs (small and medium-sized entrepreneurs) - are often based on lifestyle entrepreneurships that are strongly embedded in places, environments and communities. For example, the rationale of the entrepreneurship can be based on the opportunity that taking part in tourism gives to live in a specific place, to be part of a certain community, or to experience activities and lifestyles in a distinct environment. These lifestyle-related considerations often incorporate the seasonal flows of a tourism operation over the course of a year, where there are benefits associated with working only part of the year. Typically, this translates in practice into the ability to enjoy free time the rest of the year (Gunnarsdóttir \& Jóhannesson, 2014).

The priorities of such local actors can be strongly marked by adapting to the rhythm and annual life cycle of the place, of the community and of the environment of which they are part. Accordingly, lifestyle entrepreneurship also relates to seasonality as a necessity: for instance, in the case of Sámi reindeer herders in Norway who have a long tradition of taking part in summer tourism along the coast of northern Norway. To understand this fully, it is important to bear in mind that SMEs are often run according to a logic that contradicts the general idea of the capitalist economy founded on maximizing capital accumulation and profits as the primary motivating feature. Since lifestyle entrepreneurs are the main providers of attractions and suppliers of experience products in Arctic communities, the issues they face in relation to seasonality feature prominently (see de la Barre, 2013).

Other SME entrepreneurs see opportunities to develop their activities and perceive all-year-round tourism as an attractive opportunity allowing them to "reduce the economic pressure". As stated by a workshop entrepreneur whose family runs an allyear-round dog-sledding company, there is a need to fit the needs of the dogs to allyear activities, which provides better opportunities to emphasize the "learning about dogs" aspect of the tourism experience they offer. In this case, they consider it a core value in their experience product. Moreover, SMEs that diversify into other, possibly non-tourism-related, income-generating activities across an annual calendar, and that may not yet generate enough income from tourism, may also favour year-round tourism initiatives.

Another example is found with indigenous entrepreneurs, who may rely on seasonal engagement in tourism to make the entrepreneurship fit into the annual life cycle of their land-based or community activities (e.g., hunting or cultural offerings based on seasonal change, as in the Sámi reindeer herders example provided above). Some-times seasonal tourism products are developed in the same geographical spots that are used in the semi-nomadic practices of, for example, reindeer herding. This is done to allow partners and family members not directly involved in reindeer herding to stay together with their reindeer herding partner (Müller \& Pettersson, 2001). These practices or strategies apply also to the Canadian indigenous tourism context in that indigenous culture-based tourism offerings encounter constraints due to the 
requirements of traditional land-based activities. Up to now, these seasonally based and subsistence-oriented activities have largely not been commercialized for the purposes of tourism. The cultural commitment to participate in these activities, however, may influence the indigenous ability to participate in offering tourism if they have not been able to commercialize their practices for tourism. Nonetheless, during the winter of 2017/2018 the Indigenous Tourism Association of Canada highlighted emerging indigenous winter tourism experiences (ITAC, 2018), which also coincided with an increase in the demand for indigenous tourism in Canada (Times Colonist, 2019).

Strong seasonality-expansion mandates that connect weakly to such locally owned SMEs can, however, put pressure on local communities without "paying off" locally in a similar way: for example, in terms of employment or other local economic gains. One example where this connection is challenging is in Honningsvåg, northern Norway, where externally owned facilities are found, showcasing North Cape, and where summer cruise tourism is strong. The community has adapted well to the presence of cruise tourists and foreign seasonal workers, who do most of the guiding during the summer peak season. However, the opportunities for local ownership, local employment and to increase local investments through all-year-round tourism is a topic related to community development, due to the sociocultural instability, the environmental pressure and the economic downside that the strong peak season now implies.

An important element of sustainable community development is local ownership of business activities that operate locally. Local ownership improves the chances of further local investments of economic surplus from tourism. Local ownership can be accompanied by long-term responsibility and engagements in continuing local development processes alongside other industries and with varying interests present. Accordingly, an important topic is how seasonality may hinder or prepare for such local ownership in tourism (see Chapter 3 ).

\subsection{Business and corporate tourism leaders}

Year-round tourism is needed to create space for local investors and entrepreneurs to establish certain types of medium-sized businesses that provide functions and services that can compete with big companies that are externally owned. The medium-sized and larger locally owned companies often coordinate much of the nature-based tourism guiding activities in and around the towns and main resorts. They also compete with global tourism companies like booking.com. One of the representatives of a locally owned larger company emphasized in the focus group discussions that the economy of year-round tourism is necessary for their business to be viable. In the panel discussion, it was pointed out that year-round tourism also enables larger companies to deal with environmental issues, and to recruit competent staff, who demand full-time positions. Added to this, having some more financially robust local companies based on all-year tourism can ensure that further investments are made locally.

Communities may or may not (want to) catch up, or even be able to. Human resource issues in the form of labour and capacity often quickly emerge as foundational 
issues to be resolved. However, since many Arctic communities are challenged by outmigration, the role of tourism in their futures often relies on the tourism industry's ability to provide opportunities for all-year employment.

A question to investigate, then, is to what extent larger businesses drive the seasonality objectives found in small places, and what interest they actually have in contributing to local communities and their economies and well-being. Larger companies are driven by cost analyses that rely on expanded infrastructure that only makes economic sense when the infrastructure can be used all year round. Small companies are not typically able to contribute to the establishment of large and costly infrastructure development. On the other hand, if the community takes part in investing, then companies may be able to move in and out but leave the cost to the communities. One example of this is the cost of expanding airports and giving discounts on fees in order to get low-cost carriers to operate. Conversely, these expanded services, once developed, are also available for local inhabitants and can support community development, but less so if services, facilities and activities are only open during the peak season.

\subsection{Destination management organizations and the public sector}

DMOs and public sector actors are examples of major players in tourism development that understand tourism development and seasonality from a general perspective where all-year-round tourism is the preferable outcome. For example, DMOs are entwined with shaping visitor perspectives, which in turn play a significant role in expanding tourism seasons. Promotion and marketing are highlighted as one arena where "new" seasons can be "created" through the way destinations are discursively represented. However, and depending on how places are represented, visitor expectations may clash with what communities feel comfortable with. "Sense of place" disruptions are key aspects involved in authenticity discussions in tourism settings.

Hence, seen from the perspective of tourism entrepreneurs, managers and scholars in the Arctic region, seasonality can be viewed as both an opportunity and a problem. Another example of the former is indigenous entrepreneurs, who may rely on seasonal engagement in tourism to make the entrepreneurship fit into the annual life cycle of their indigenous community. An example of a position from which seasonality is first and foremost seen as a problem is the DMO or public sector actors (e.g., government tourism or economic development departments) that identify the possibility of economic growth underpinning the development of all-year-round tourism. Both examples illustrate well how sociocultural and environmental as well as economic sustainability of future Arctic tourism may be inherent in arguments both for and against seasonality. This indicates that when seasonality in tourism is the issue, policymaking and management strategies should be attuned to, and make room for, specific local conditions that may identify all-year tourism as a threat or opportunity in a specific context. 


\subsection{Conclusion}

In the future scenarios workshop, the group working with the scenario for northern Sweden generated overarching discussion on the Arctic in general in light of the multination composition of the focus group. Critical debate occurred under the heading "Utopia or Dystopia", and identified several key future-oriented strategies, which can be positioned under the community section heading of this report. These include:

- the need for a "cultural shift" in how tourism is produced and consumed; this shift would include "radical creativity" as a means of responding to nature-based and culturally/socially embedded tourism development challenges;

- developing "values-based" visitor markets: for instance, integrating host and guest perspectives and practices based on "solidarity" between human and animal species;

- encouraging prolonged visitor stays in a region;

- enhancing Arctic urban adventures to mitigate the use of fragile natural environments, and making the most of urban infrastructure (existing and anticipated);

- enhancing international consensus on tourism development initiatives and respect for Arctic cultures and environments;

- advancing and rewarding sustainable transportation initiatives (both host destination supporters and guest users);

- addressing labour issues endemic to the tourism sector, including wages and benefits, valuation of tourism-related employment, and opportunities for employment diversity and advancement;

- increasing destinations' ability to support innovation, new tourism business development and creative approaches to tourism development.

One way of approaching the phenomenon of seasonality beyond such differing and partly contradicting perspectives of actors in the tourism industry is to look at the topic from a local community perspective. Long-term sustainable development of Arctic tourism relies on the local environmental, sociocultural and economic entanglements of touristic practices. The sustainability discourse stimulates that of paying attention to how tourism intertwines in local environments, and is embedded in local communities and enmeshed in local economies. The long-term perspective inherent in engaging in community development and caring for environments can be a resource for those who work to promote sustainable tourism futures. This long-term rationale provides a framework for exploring how to deal with seasonality in management and policymaking aimed at sustainable tourism development. The question is whether natural environments and communities can take the pressure of strong seasonality or can live well with all-year-round tourism. To answer such questions, the specific characteristics of the local context must be carefully considered. 


\title{
3. Employment and workforce issues
}

\begin{abstract}
In this chapter, employment and workforce issues are discussed from the perspectives of labour availability, capacity building and income security. The seasonal characteristics of Arctic tourism have created an imbalance in operations and delivered a huge challenge in relation to the workforce. Employers highlight that it is both difficult to recruit skilled employees and retain them while employees face difficulties in building up long-term careers within the sector. Local tourist companies face fierce competition from national or international operators that are better placed to hire skilled workers and relocate them as suitable for their business according to seasonality. Seasonality is a central barrier to develop tourism's ability to provide meaningful employment as well as opportunities for advancement in the Arctic region.
\end{abstract}

\subsection{Introduction}

Given the sheer size of the tourism sector in the global economy it is an interesting fact that issues of tourism workforce and employment are in general an understudied area within tourism research. Tourism employment reflects the diversity of the sector in terms of jobs and skill demands. Robinson, Martins, Solnet, and Baum (2019) point out that the diversity of tourism employment makes it difficult to make generalizations about workforce issues. What is certain, though, is, as Baum (2007, p. 1383) states:

[t] he story of successful tourism enterprises is one that is largely about people - how they are recruited, how they are managed, how they are trained and educated, how they are valued and rewarded, and how they are supported through a process of continuous learning and career development.

While Baum is deliberately only referring to the "people" of the tourism enterprises, critical factors for sustainable tourism development such as the sociocultural embeddedness of the tourism industry and the environmental responsibility practised by it are also very much about people and their relationships; that is, how the workforce becomes, or does not become, part of local communities and gives back to the host society in various ways (Robinson et al., 2019).

The relationship between labour and workforce issues and seasonality is often positioned at the centre of critical tourism development discussions in the Arctic region; these discussions are also framed as both challenges and opportunities associated with tourism. Labour and workforce issues intersect with different dimensions of tourism development in Arctic communities, which in turn impact on seasonality. These 
dimensions include available labour, capacity building and training, and income and income security. These dimensions are also influenced by other factors, such as competition with resource extraction industries, the image of the sector and the need to provide meaningful tourism employment, including opportunities for advancement.

\subsection{Available labour}

Although there are places in the region that enjoy a relatively stable demand for tourism and thus little seasonal fluctuation, such as Reykjavik, Iceland, in general tourism in the Arctic is characterized by stark seasonality. The seasonal characteristics of Arctic tourism have created an imbalance in operations and delivered a huge challenge in relation to the workforce. While there may be plenty of available jobs part of the year, permanent, year-round jobs are scarce or unavailable. This makes it difficult to recruit and retain workers even though in some places there is considerable unemployment and thus, in theory, available human resources. The problem is that the available labour force does not necessarily possess the skills and competence needed for a job in the tourism service economy, while due to the seasonal fluctuations it is difficult to convince the skilled (migrant) labour force to settle down. One of the participants in our focus groups reflects on the situation:

It's kind of easy to find a workforce for, let's say, the guiding and the really basic tasks ... but how to keep ... the good ones working around the year when we can't actually offer work around the year? ... And if you want to keep up the quality of your services, you need to start hiring people in key positions that you can't keep around the year. (Participant in focus group 4)

This quote echoes the discussion above about the challenges local companies face when competing with bigger national and international rivals. It also underlines a critical threshold that many companies are facing: namely that while it may be possible to recruit people for low-level or low-skill jobs, it is difficult to hire people with the skills and capacities needed to run a company that is able to compete with larger non-local players. "It is because it is not really a factory job", says the participant from the focus group, underlining that it takes time to build up the experience and knowledge needed to manage a tourism company in a highly dynamic and competitive environment and it is important to be able to work full-time in the sector to build up the necessary competence.

A related theme is that many people working in tourism like to be mobile and move between jobs and places, which blurs the distinction between the "tourist" and the "worker" (Uriely, 2001). It is a matter of lifestyle choices or volunteer tourism especially poignant given the relatively young demographic that usually populates tourism's service sector employment. This point touches on a broad-ranging issue in relation to the organization of the labour market and its regulation that revolves around mobility and moorings (Hannam, Sheller, \& Urry, 2006), which shape the labour geographies of the Arctic and sub-Arctic region as elsewhere. On the one hand, it can 
be positive to be able to move or travel around for seasonal work, especially if this involves higher-skilled workers who can bring with them important know-how for local operators. However, when people would like to settle down and build up their lives working in tourism in a particular place, seasonality becomes problematic. It also depends on what kind of job or career people are seeking. Moving between destinations for employment, depending on seasons, may work for some guiding work and lowerlevel service jobs but is more difficult to envision in middle management, for instance.

The mobility and potential movement of labour also relates to debates about labour precarity and the emerging precariat in the global tourism economy (Lee, Hampton, \& Jeyacheya, 2015; Strauss, 2018). Robinson et al. (2019) argue that the tourism industry can be seen to sustain precarity through its employment practices. Tourism is heavily dependent on a mobile labour force, not least to respond to seasonal variations in demand. The more volatile jobs are often staffed with non-local labourers, including migrant workers that often face precarious and exploitative working conditions. Baum, Kralj, Robinson, \& Solnet (2016, p. 15) list what they call the "dominant stigmas" of the tourism industry such as "low skills/deskilling, low entry barriers, the $365 / 24 / 7$ demand for service, poor working conditions, intrinsically unrewarding repetitive jobs ... precarious and/or seasonal employment". Furthermore, tourism is arguably a key driver of the collaborative and sharing economy as manifested by the rising popularity of Airbnb and similar sharing platforms. The long-term consequences for employment and workforce are still unclear but are likely to increase precarious work, in terms of working conditions characterized by a lack of security, regulation and predictability (Robinson et al., 2019).

While it is unfair to describe all tourism along these lines it is undeniable that these characteristics of some of the tourism sector influence how it is perceived in a general way by the community and economic development leaders. The perception is that, since tourism is seasonal, it is unable to support mandates that seek to retain existing residents, or those that aim to attract new long-term residents, and is not offering clear career paths that might counteract this image. In focus group 1 an example of mountain guides in the Alps was taken to describe how it is possible to build up an image of guiding as a prestigious job with a long-term career path. Many examples also exist of tourism companies actively seeking to enhance their corporate social responsibility (see, for example, the responsible tourism initiative under the umbrella of the Icelandic tourism cluster: http://www.icelandtourism.is/verkefni/abyrg-ferdathjonusta/). The negative image of tourism seems, however, to prevail. Municipalities' authorities are thus reluctant to invest in the infrastructure necessary for sustaining whole-year tourism. A local participant in focus group 4 described this situation in the following way:

\footnotetext{
And I think it's perceived to be seasonal, so there doesn't need to be investment because it's only seasonal. And I think it ripples down into staff perception and employment perception. If it was year-round and strong year-round, it would automatically garner new private sector investment. It garners a new positive reputation and new support monetarily from government. So, I think we're on this platform of being perceived and being told that we're important, but we're not being given the support by government that we should be.
} 


\subsection{Capacity building and training}

While tourism experiences are place bound and are consumed or co-produced in situ, both employers and employees may be mobile. Therefore, local tourist companies can face fierce competition from operators or businesses that relocate to the tourism destination only to reap the profit of the high season without having any obligation to the host communities when the season is over. As a result, long-term benefits of tourism may be undermined for the sedentary host community. Transnational companies are better placed to hire skilled workers and relocate them as suitable for their business according to seasonality. The impression from the focus groups, however, is that there is a limited number of people that actually like the lifestyle of travelling the world to work in tourism in different places at different times of the year and it applies only to particular jobs. But this group is definitely visible:

We have some of our guides, they are working winter for us and then in the summer they go to Norway, some go to Iceland, some go to southern Europe. So, they can do the same kind of guiding work but in different fields in different countries for different companies, because the seasons are different all over the world. Some of them want to do that. But again, there is still a limited number of people that want to have that kind of lifestyle. (Participant in focus group 2)

From the perspective of the people leading this kind of lifestyle, seasonality is not a negative thing but actually provides them with the desired flexibility in their working life. As we saw above, from the local company perspective this is something that needs to be changed, not least to secure and improve the quality of the services provided. To build up a more economically sustainable business it is of utmost importance to be able to provide people with more permanent jobs when they want to settle down.

An issue often noted as problematic is that the seasonal workers that come to the peripheral areas are not knowledgeable enough about the region they are working in and even the products they are working with. This is an interesting dilemma since at the same time it may be difficult to find skilled local people to work in the tourism sector. This leads some to pose the questions: "What does it mean to be local?" and "What is local to the Arctic?" (Tuulentie \& Heimtun, 2014).

The mobile and transient nature of tourism may also negatively affect the integration of tourism operations with the fabric of the host communities as workers tend to come and go without having to become full members of those communities and operationalize citizenship-based contributions. An issue often mentioned as problematic is that seasonal workers do not pay tax to their host community but only to the municipality where they have their legal residency. As mentioned above, municipalities are reluctant to build the infrastructure necessary for whole-year tourism, such as the necessary housing and services, in the current situation when it is highly likely that it will not be used during the low season. Some businesses respond by building or providing housing for their employees. While that may be part of the solution it also creates a risk of exploitation when companies, for instance, decide on both salaries and the rental prices their employees need to pay them for housing while they are working for them. Currently, both tourism businesses and the communities in 
the region are experiencing a paradoxical "catch-22 situation": On the one hand the infrastructure presently available is too limited for further growth during the high season, while on the other hand because of the limited infrastructure, it is not viable to run tourism the whole year round. For some, the best way forward would be to have a full operation running for approximately 10 months a year and then there would be no need to grow during the high season. The implication of the current imbalance is that "the whole normal way of building municipalities does not work with seasonality" (participant in focus group 3).

As mentioned above, seasonality negatively affects the image of tourism as a sector that is able to offer interesting and rewarding jobs. But there is another side to that debate. Indeed, the mobile and transient nature of the tourism workforce creates a strain on businesses that need to invest repeatedly in the hiring and training of new staff. In addition, different seasons require different kinds of skills and knowledge: working as a ski instructor, for example, is not the same as working as a bike instructor. As a result, however, this organically creates diverse types of jobs within the tourism sector. This diversity may work in tourism's favour given that service sector jobs are attractive to a younger demographic seeking transient, versatile and temporary adventure in the peripheral areas. As an extension to this observation, a little discussed attribute of tourism is its ability to shape and prepare workers of the future. A large proportion of the workforce in tourism is made up of young people. Tourism is the unacknowledged and undervalued training ground that is accountable for its role in preparing new generations of workers that transfer into any number of other sectors with skills and knowledge acquired in one of the most complex customer service sectors.

\subsection{Income and income security}

When it comes to being able to provide income and income stability to those who live in the Arctic, communities have long relied on the resource extraction industries (e.g., oil and gas, mining, forestry and fishing). Tourism income is an awkward competitor in this regard. Therefore, the added necessity for tourism to enhance its ability to provide meaningful employment as well as opportunities for advancement is critical. Seasonality is seen by many as a central barrier to accomplishing that. Nonetheless, it is evident that for some lifestyle entrepreneurs, for example, the intentional design of seasonal work is not an obstacle but rather the attraction of the sector. Seasonal work provides them with time to rest and recharge after a hectic tourist season, avoid burnout and achieve work-life balance goals (Jóhannesson \& Lund, 2018). The same is likely to be true for at least some jobs in Arctic tourism. Guiding is well known to be emotionally draining and it is important that people get the recovery time they need in order to stay in the profession (Heimtun, 2016; Penttonen, 2018).

A question that derives from this theme is whether or not year-round tourism issues are resolved only by having larger tourism businesses, which by necessity requires a different kind of infrastructure. This infrastructure may provide year-round jobs but 
may also negatively impact upon community "sense of place". The key question that needs to be addressed in this context is how to develop tourism that strengthens communities and makes them better places to live in, which further begs the question of how to find the balance between economic, social and environmental sustainability.

\subsection{Conclusion}

The above labour related-themes and the associated challenges and opportunities vary across time and space, and impact differently upon the multiple geographies within Arctic regions. For instance, there is an increasing need to consider how to "push" tourism outside core Arctic areas to the smaller, more remote, less accessible communities on the periphery (e.g., in the case of Reykjavik, Iceland, or Whitehorse, Canada). Developing tourism in small or remote localities may mean that centres and remote communities cooperate to ensure a more viable seasonal distribution of tourism in towns and rural villages alike. It may also mean that entrepreneurs need to seek alternative ways to the usual modes of "doing" tourism business: for instance, partnerships between core-based businesses and smaller, even more remote communities that struggle with not having any tourism, let alone enhancing new season offerings. Indeed, spatially sensitive innovation strategies may place more emphasis on collaboration between core and periphery-based businesses such as through cooperatives, making it easier to accomplish a work-life balance, stronger municipal control on access to and the right to use resources, and regional- or nationallevel support systems that can work with and accommodate place-specific conditions and problematics. Attracting tourism to the latter communities entails issues outside the scope of seasonality, but certainly lies within the scope of the broader discussion on the impacts of seasonality.

It is crucial that in the process, tourism stakeholders, including local communities, think about the values of tourism and how it can matter for making economies and cultures stronger. Taken only as a tool for economic development or framed in simple terms according to the economic rationality of the growth paradigm (Viken, 2014), the risk is to develop tourism as a parasite industry living off the communities instead of sustaining them and building their overall resilience.

It is important to explore the meaning of seasonality for those working in tourism, as well as for those who employ its workers. Importantly, there is a critical need to investigate what the difference is between seasonal tourism and seasonality in tourism, and assess the way forward based on place-specific responses and development objectives. 


\title{
4. Arctification of northern tourism
}

\begin{abstract}
In this chapter, the impact of producing, performing and consuming northern Europe as Arctic is discussed by illustrating the linkages between "Arctification" and seasonality. The Arctification of the European North has altered the preconditions for tourism by providing greater media attention and by triggering touristic demand. At the same time, Arctification entails a number of challenges, such as stereotypical images of the North as cold and snowy, which have implied a neglect of the distinct environmental seasons of high latitudes. This applies to marketing of the region but also to the expectations held by tourists and seasonal workers. Arctification also leads to a greater accentuation of the winter season as the main season.
\end{abstract}

\subsection{The image of the North and the Arctic}

For a long time, northern environments have attracted travellers from southern regions. Initially this was related to ideas of encountering the edge of the world, the unknown and mystical Ultima Thule, signified by ice and snow (Jacobsen, 1997). Not least during the 19th century, the epoch of polar exploration, media and fiction emphasized adventures in the North as heroic and masculine (Hansson, 2015, 2018). Furthermore, it stereotypically portrayed the North as nature and wilderness, at the same time disregarding the presence of indigenous peoples and other northern populations. Still today this idea persists, as, for example, the search for Erebus and Terror, the until recently lost vessels of the Franklin expedition in search of the Northwest Passage, powerfully underlines (Dodds \& Nuttall, 2016).

At the same time, climate change and the consecutive consequences for transportation and resource extraction, but also indigenous industries such as reindeer herding, imply an increased public interest in the Arctic region. Stakeholders such as environmental organizations, science councils and politicians are just some of those dwelling on this recent interest in the North. They compete with scenarios and visions for the future of the region. Without doubt, they sketch an image of a contested region in rapid change. Even media and fiction have recognized the changing Arctic, portraying it increasingly in the context of climate change, but continually stressing its characteristics as a masculine wilderness, frontier and empty space (Hansson, 2015; Loftsdóttir, 2015). In this context, popular television shows featuring life and work in northern environments contribute to images of the north as different and marginal (Loftsdóttir, Kjartansdóttir, \& Lund, 2017). 
The search for adventure in pristine environments has even been upheld by modern tourism and travel (Jacobsen, 1997) identifying northern destinations as desirable playgrounds for southern urbanites (Pedersen \& Viken, 1996). The penetration of the northern space by modern infrastructure improving accessibility dramatically has created preconditions for growing tourist numbers (Hall \& Saarinen 2010b; Lundgren, 1995, 2001; Müller, 2015), and in fact, the previously dominant summer season is now accompanied by a stronger winter season. In some places, such as Rovaniemi and Jukkasjärvi, the winter seasons have turned into the major tourist seasons for destinations (Grenier, 2007; Müller, 2011).

However, the constant availability of Arctic issues in media has triggered new interests when it comes to tourist demand. Hence, Lemelin, Dawson, Stewart, Maher, and Lück (2010) claim that the contested Arctic region increasingly attracts tourists utilizing the last chance to see the threatened and maybe disappearing Arctic environments. DMOs and tourist enterprises seize economic opportunities in this situation. This is manifested in various ways, which will be discussed below. However, a common feature in this context is that the European North is increasingly being rebranded as Arctic. This is true not only for the tourism industry but also for various other public and commercial bodies such as universities that increasingly use the labels "Arctic" and "polar" for signifying their initiatives and products as different and original.

These changes have an impact on how tourism in general, and seasonality in particular, is produced, performed and consumed in the North, as will be discussed in the following sections.

\subsection{A review of tourism practices and products in the North}

Historically tourism in northern Europe has included notably nature-based summer tourism. Long-distance hiking and other outdoor recreation have been dominant features of the northern tourism supplies. However, at least in the Swedish case, demand stagnated and indeed it seems that there were problems in recruiting new hikers to the mountain regions (Fredman, Emmelin, Heberlein, \& Yuorio, 2001; WallReinius \& Bäck, 2011). Furthermore, Wall-Reinius and Bäck (2011) found that the average ages of hikers, as well as their acceptance of infrastructure providing accessibility and comfort, increased with time. Simultaneously stated interest in adventure in a perceived wilderness environment grew too. This softening of adventure tourism has also been noted in Finland, where commercial nature-based activities consist most often of highly organized and industrialized guided services for the unskilled market (Rantala et al., 2018). Accordingly, there are some recent examples of organized hiking activities, such as the Lapland Classic organized in Pallas-Yllästunturi National Park:

Yes. I think there is a market, even in the domestic market, for these kinds of things when people are now working. They are earning good salaries. If the retired payment keeps to a level and people can have this kind of high level of lifestyle when they are retired. I think it is ... when people that are used to buying services and used to making their holidays easy. (Participant in focus group 2) 
When preconditions allowed it, Alpine tourism facilities were established. This happened in Sweden during the 1960 s and 1970 s and often entailed resort-like growth that was focused early on mainly on the winter season (Bodén \& Rosenberg, 2004; Fredman et al., 2001). Hence, in Sweden, by the end of the 2oth century, Alpine skiing had exceeded Nordic skiing in popularity by far. Even the use of snowmobiles turned out to be an increasingly popular winter activity (Fredman et al., 2001). However, in Arctic Sweden this development often remained small-scale (Müller, 2019). In Finland, a similar development took place, but somewhat later (Saarinen, 2003). In contrast to northern Sweden, however, the development exceeded just catering for a regional demand. Instead, resorts such as Levi and Ylläs now attract visitors from the entire country and even abroad - during the last three years the number of foreign visitors has exceeded that of domestic visitors in western Lapland (Ylläs-Levi area) during the winter season. During the summer season, national tourism still exceeds considerably the amount of international tourism (Visit Finland, 2019).

Besides these traditional rural tourism activities (cf. Butler, 1998), new tourism products appeared or developed into more significant activities. Certainly, these products meet at least some of Butler's characteristics for new activities. Hence, products are more individualistic, costlier and more prestigious than during previous periods. Butler spotted, however, that new rural activities would be less related to the rural landscape. This cannot be supported totally. Instead, it seems that activities are highly landscape based, which, in relation to the seasonal characteristics of the new products, means that many of them require snow, ice or darkness in order to be consumable. The turn towards winter activities has thus implied a greater significance of seasonal landscape-based experiences. In contrast to summer activities, these new activities require service infrastructure and touristic services, and thus provide greater opportunity for economic revenue. Moreover, these products are increasingly framed and promoted as Arctic.

One of the most prominent recent tourism products is Northern Lights watching, which is now available all over the Nordic region. Hot spots can be found, for example, in Tromsø, Abisko and Rovaniemi, and markets seem to cover all parts of the world, particularly Asia, Europe and North America, where they seem to be more prominent than before. Products usually comprise night-time chasing tours, looking for spectacular sights. Regardless of commonalities, several factors separate the tours and destinations (Heimtun et al., 2014). The Norwegian Northern Lights tours, for instance, tend to be more expensive and they often last longer. In Finland, most of the tours are combined with other outdoor activities. Mass tourism is most noticeable in Reykjavik and the tours are the cheapest there. However, considerable product development has taken place in Iceland recently. Mass tourism is still the most prominent, but offers of different kinds of combinations are very popular: for instance, a spa and Northern Lights hunt, or local food experiences and Northern Lights hunts. Winter tourism seems to be very dynamic. Furthermore, in Iceland and in Alta (Norway) mostly local guides are employed, whereas in Finnish Lapland and in Tromsø (Norway) many workers are from other European countries (Heimtun et al., 2014). All in all, the Northern Lights have been developed into a product that has become a key aspect of developing winter 
tourism in the Arctic, sold as a mystical and romantic experience that contributes to a particular image of the Arctic as mysterious and magical (Jóhannesson \& Lund, 2017). In addition, Northern Lights tourism illustrates how these new activities require service infrastructure and touristic services: the role of guides as "stage managers" is highlighted within Northern Lights tours as well as the role of service providers and service infrastructure in recognizing and productizing different lightscapes and rhythms (Jóhannesson \& Lund, 2017; Rantala \& Valtonen, 2014). Recognizing better the importance of guides in the process of Arctification may have a positive impact on their position and salaries:

\footnotetext{
We do know already that we pay in the wintertime for the trips that start really late, that you need to work really late hours. We pay more for those hours. The Aurora trips are so much in demand. We need a lot of workforce, but people are not so keen to go every night because it's quite a hard job. Especially when it's snowing like hell and you are going out with a group of people to see the Northern Lights and you know that there is no chance of seeing them. It's mentally really hard for the guide to keep up their spirit for the three hours for the clients when there is snow and really shitty weather and the people are really expecting to see the Northern Lights. It's a really demanding job and you want them to pay a little bit more for that time. (Participant in focus group 2)
}

In 2018, Vancouver (British Columbia) $\left(49.3^{\circ} \mathrm{N}\right)$ held its first ever "Aurora Winter Festival" in the weeks leading up to Christmas (December 25). The City of Vancouver, located in the lower mainland area of the province, has average temperatures from November to February of between $5^{\circ}$ and $10^{\circ}$ Celsius, and does not typically have much, or any, annual snowfall (Tourism Vancouver, 2019). Yet the new festival's promotional campaign invited the visitor to:

Escape into a hidden village by the North Pole filled with captivating light displays and magical
characters ... From visiting Santa's Workshop to lacing up your skates on the Frozen River, there is
something for every age at the Aurora Winter Festival.

The "frozen river" in this case is an outdoor rink, and not a natural body of frozen water (Aurora Winter Festival, 2018).

Another recent phenomenon that has partly resulted from the increasing interest in the Northern Lights and from the product development around it, and partly from the long-standing expertise on snow construction (see Härkönen, Jokela, \& Yliharju, 2014), is the construction of different kinds of igloo villages in Finnish Lapland. The igloos with glass roofs make it possible to watch the Northern Lights while in bed. Similar facilities are also increasingly available elsewhere in the northern region. Hence, the interest in the Northern Lights has been linked to the trend for well-being, sleep and accommodation offering more than a standard hotel experience.

Another product that can now be found frequently in the Nordic region is companies offering dog-sledding tours. Dog-sledding tours in Arctic Europe are associated with the tradition of Arctic expedition and racing culture, especially in northern Norway. 
But that's actually an interesting question in terms of huskies ... where we have the Finnmark Race. I don't know if you're familiar with it? And there's a lot of dog sledgers that have settled in the area, just because it's very [good] for dog sledding. And it's starting to have a longer tradition there. So, it's perhaps a part of the culture, because there's so many people, local people, who are not doing the sledding for tourism, because they have generally a passion for it. Though many of them ... come from different parts of Norway, or even from different parts of the world. So, it's also not necessarily local people who are doing it, but it's becoming sort of a local tradition in a way.

(Participant in focus group 3)

The dog-sledding culture in northern Norway is an example of the new northern "natureculture" that is not being developed for tourism purposes but is supporting the development of tourism in these regions (Granås, 2018). The new natureculture constructs Arctic Europe not only as pure nature and as a vast wilderness empty of people but as places where international mushing cultures and sled dog breeds can be encountered, where polar expedition history is brought to life, and where local environmental circumstances are utilized for the renewal of outdoor practices and nature traditions (see Granås, 2018). In Finnmark, Norway, the local ownership of dogsledding is strong, as well as the participation in, and support for, organizing the yearly Finnmark Race, and this helps in constructing pride in the new outdoor practice (Granås, 2018). In northern Finland, dog-sledding started with the same kind of expedition and racing culture, but the rapid increase in tourism shifted the focus towards commercial tourism activity. However, recent events (such as Lapland Quest organized in January 2018 in Ylläs, Finland) indicate that the sled-dog culture beyond commercial tourism is still lively.

Other outdoor activities resemble the idea of the Arctic North as an arena and playground (Pedersen \& Viken, 1996). Canoeing, rafting and canyoning are some of the activities that are reminiscent of frontier cultures and an imagined hardship of life in the wilderness. Combined with an increasing sportification in the spirit of a "new rural tourism", this also entails products and events that are marketed as multisports. Similarly, skiing and mountain biking cultures are strong in certain resorts and areas. Hence, in these areas one can find, for example, very specialized and good sports shops - even though there is a lack of other services. Furthermore, in focus group 3 these new adventurous northern naturecultures were seen to offer a kind of ethically sound base for product development in tourism: "The definition of culture is so broad too in terms of like mountain biking culture and dog-sledding culture versus indigenous culture, right? It's very different and that's when you bring in those ethical... In my opinion at least, l'd be more confident in altering, say, mountain biking culture than ... entering in and making changes to something like a community culture..."

For example, there are fatbike products being developed for the winter season and roller skiing products being developed for the summer season. In addition, electronic bikes allow inexperienced visitors to be introduced to biking products. The development of new cultures and new products is related to the availability of a skilled workforce: Ylläs in northern Finland is becoming a mountain biking destination and trying to engage ski schools in training a skilled workforce by encouraging ski instructors to become biking guides. 
I think it's the same thing with mountain biking. You don't need to be a sort of a hard-core mountain biker to be a mountain biking guide in a way. Or you have, you know, one or two highly competent guides for those very high-skilled clients, but the rest of your staff is very generic. (Participant in focus group 3)

The development of new Arctic products is not only related to new local cultures, but also to the "softening" of Arctic tourism. It was pointed out in the focus group discussions that in future - due to climate change - there will be fewer and fewer people who actually will know how to ski and who will own the skiing equipment. Already snowshoeing services are being offered for those who do not know how to ski. In addition, it was pointed out that in future there will be a need to fit, for example, sleddog products to the image and skills of those who are buying the products.

\footnotetext{
But then after the economic crisis around 2007, 2008 these people didn't have the money to travel anymore. And so, the companies had to find someone else and ... a lot of retired English people ended up being the main source of income. And that's how the situation is today, and they often do very short trips like maybe two hours [on the sled]. And you have to really help them onto the sled and be sure that they don't break every bone in their body, because it's a very different kind of client. Of course, you still have the other more experienced or more adventurous tourists, but a lot of them now have ended up being a fragile or soft tourist. (Participant in focus group 3 )
}

It was also mentioned that tourists often wish to experience a "Disney version" of dogsledding or reindeer services, rather than experiencing the actual authentic everyday life of the reindeer and sled dog. Many tour operators wish to have native-speaking guides for their customers. Hence, in the focus group discussion it was pointed out that the French and German guides, for example, are very professional but not local, and that those guides are suitable for visitors who want an easy holiday, but at the same time there are more and more small local companies offering the services only in English, with a personal touch.

The Disney-type image of the Arctic was also seen in the travel diaries of students. Here, the Arctic landscapes and nature were referred to as imaginary places, often described as part of a fairy tale.

At night, we went to..., a resort on a small island. You need to go across the bridge to get into it. It gives a kind of Shangri-La feeling. (Travel diary 1 )

In truth, it was a magical journey through the inspiring winter landscape. The sun cast a golden hue across the icy trees .... (Travel diary 3 )

In the travel diaries, the Santa Claus and the Disney-type images of the Arctic entwine together.

... it was hard not to feel a little enchanted when faced with the first glimpse of Santa's workshop.

Despite the lack of snow, once we'd passed the gift shops galore of the entrance, it was like

entering a childhood dream. (Travel diary 3 ) 
Also, the absence of snow did not seem to affect significantly the visit of the Santa Claus village during late October. For example, the snow cover of the place was something you could imagine in your mind.

Located in the woods, when driving into the area it seemed very quiet. I could imagine when the

place is covered in snow how magical it could look, with Christmas lights. (Travel diary 2)

In the students' diaries, the idea of an authentic Arctic nature was comprehended in different ways. Some of the students were disappointed in hiking in nature as they considered the authentic Arctic nature to be something different from the Arctic Circle Hiking Area situated near to Rovaniemi.

For me it didn't feel like a nature experience, there was a lot of man-made constructs: rest spots, campfire sites etc. (Travel diary 5)

Some of the students explained this by the differences between different countries. In Finland, for example, many hiking areas have duckboards to protect the nature and to enable a passage through rough terrain.

\subsection{Arctification and its unintended consequences}

"Arctification" can be defined as follows: "...it can be seen as a social process creating new geographical images of the North of Europe as part of the Arctic and ... new social, economic and political relations to the area" (Müller \& Viken, 2017). Our data show that there is an Arctification process going on, which affirms the image related to winter and snow. An example of reaffirmation of the winter image is the establishment of Winter World in Helsinki in 2010. Winter World is situated indoors in a big hall and is marketed as an opportunity to experience Lapland without needing to travel so far. Its high season lasts from the beginning of May till the end of August and during wintertime it is open for bigger groups, but the web page also invites people to visit the "actual" Lapland from September until April. One of the entrepreneurs who participated in the focus groups pointed out that they are able to run their business in Rovaniemi with the earnings from two dog teams working at Winter World during the summer season. The same entrepreneur saw Winter World as an opportunity to make income to develop the actual activities. Furthermore, she pointed out: "...of course we know what the real winter looks like, but these people would never go to the winter destination. They have one or two hours inside seeing the real snow and touching the real ice, it's an experience for them."

Winter World is not the only example of reaffirmation of the winter image. In addition, snow hotels are making their business all-year round. In 2016, the Icehotel in Jukkasjärvi launched The Icehotel 365 - a permanent structure that includes luxury suites and art suites. In Kemi they now also have SnowExperience 365 , which includes IceRestaurant365 - an opportunity to stop in an ice bar or have dinner in an ice restaurant any time of the year. Furthermore, the Swedish Icehotel licensed ice bars in 
various metropolitan areas of the world contributing to stereotypical images of the European North. In addition, Santa Claus tourism in general was seen to underline the winter image of Arctic Europe during the focus group discussion. Hence, the process of Arctification seems to include aspects of Disneyfication, creating particular ideas of the northern region's nature, history and culture (Cf. Hollinshead, 1998). Here, Disneyfication refers to repackaging of culture, nature, geography and history to fit commercial expectations. Hence, the final product manages only partly to depict the social and environmental realities of the destination.

The Arctification process does not only need to mean the reaffirmation of the winter image but can also be associated with Nordic lifestyle and with the "positive potential of humanity" - as was done during the future scenario workshop. According to the future scenarios, in 2030 the Arctic brand will refer to educating travellers about a sustainable Nordic lifestyle (close relationship with nature, slow adventure and friluftsliv); travelling in a responsible way; educating young people; and being aware of the impacts of travel. According to the vision, the Arctic brand for the year 2030 will be put into practice by concentrating on specialized year-round activities that are based on place-based resources, e.g. birdwatching, home-based tourism, long hiking and skiing trips, and culture-based tourism (see "A portrait of the future" on pages 4-5). Local knowledge was seen as an important resource for the development of future tourism - because of changes taking place in natural conditions and the fragility of nature. The focus in future should be on longer stays and on proximity tourism. Furthermore, innovativeness and creativity will be needed in order for conscious choices to be made and in order to attain a high level of quality in Arctic Europe (see also the conclusion of Chapter 2).

During the focus group discussions, the eight different seasons present in Arctic Europe were mentioned several times and these were connected to local "naturecultures" and lifestyles. Naturecultures as a concept refers to nature and culture as tightly intertwined - instead of understanding them as separate entities (Haraway, 1997; Puig de la Bellacasa, 2010). Because of the specific features of each of the eight seasons, locals know which activity best fits each particular season. Similarly, previous studies have illustrated that active hobbyists visit nature all year round and have tacit knowledge about different ways of getting equipped and performing different activities (e.g., skiing, hiking, biking, kayaking) during the eight different seasons (e.g. Rantala \& Valtonen, 2014). However, in the focus group discussions many of the activities were seen as being difficult to make products from (e.g., ice skating on natural ice because the conditions are available only for a very short period that cannot be predicted). Another concern related to making products related to activities in snowless times was that many would not buy a guided service for these, since they are used to doing the activities on their own or because these activities hold culture-specific meanings. 
Our culture is to do things in nature. And also, well-being... they want to keep well-being like one category in itself. What is well-being? For me, well-being is going out into nature and building a fire and making sausages and just sitting there. That's well-being for me and it can be well-being for some foreign people that come there. They can relax. That's well-being for me, but well-being can always be like eating healthy, exercising and yoga, having a relaxing massage, meditation and so on. I think here in Finland we have well-being in our culture in a way like the nature things they are. They are one part of well-being. How can we utilize this and make a product that can sell? (Participant in focus group 2)

The Arctic as a brand is seen as very appealing and more discussion will be needed in the future due to both the general Arctification process taking place in the North and to recent industry projects that verify the Arctic brand. In focus group 2 it was pointed out that the Arctic is better known than, for example, Finnish Lapland, but it also offers opportunities for longer round trips for Asian travellers. The advantages related to the Arctic image and brand have already been recognized by the tourism industry in northern Finland, Norway and Sweden, and there is currently a second industry-led project running: Visit Arctic Europe (VAE). The VAE project aims to develop northern Scandinavia into a cross-border, high-quality tourist area that is an internationally competitive and well-known destination. The projects focus on tourism marketing, joint product development, improvement in terms of accessibility and competence development.

From an industry perspective, the focus group discussions revealed a certain concern that the focus was too much on the winter seasons today. Here the potential to grow was considered doubtful. Particularly for the Rovaniemi case where the Christmas season has been of utmost importance, industry stakeholders noted that even though winter conditions are available for a much longer time, usually at least throughout April, demand and offers remain limited (see also the results of the VAE questionnaire, Section 1.4). This also creates a seasonal peak of demand for labour that could work in the industry. Year-round employment, on the other hand, is seldom available and restricted to employees with special skills that are considered of core importance for the business. The consequence is a challenging annual recruitment process that still does not result in satisfactory outcomes. Guides have limited skills and knowledge, particularly in relation to place and local conditions, and some of the entrepreneurs are aware that this constrained quality development. Despite being marketed as easy experiences, winter conditions still require specific enskilment to act in cold environments and to use specific equipment, which is increasingly missing when tourism is softened (Rantala et al., 2018). This applies to tourists and guides equally.

A further Arctification could thus imply an amplification of these challenges, and hence, even though winter conditions could be artificially extended through snow making, not everybody is convinced that this is the right way forward.

\footnotetext{
I have a feeling that we can just produce the winter conditions when it's not really conditions for it.

... Yes, we can technologically do it, but should we, right? (Participant in focus group 3 )
} 
Industry stakeholders thought that other seasons, and particularly the autumn, are so far not sufficiently developed, although they are convinced that this would be a great opportunity. It was also noted that the increasing interest in the Arctic winter has led to a situation where industry ownership is increasingly being transferred from local stakeholders to international investors. This challenges the home-grown industry with good relations between the stakeholders and rather creates a situation where more stakeholders claimed a share of the business, also entailing competition through lower price levels.

\subsection{Conclusion}

The Arctification of the European North has altered the preconditions for tourism in various ways. Besides providing greater media attention and triggering touristic demand, Arctification entails a number of challenges. Not least, stereotypical images of the North as cold and snowy have implied a neglect of the distinct environmental seasons of high latitudes. This applies to marketing of the region but also to the expectations held by tourists and seasonal workers. Arctification also leads to a greater accentuation of the winter season as a main season, although this mainly applies to distinct winter destinations such as Rovaniemi, Kiruna, Tromsø and various skiing resorts, while other locations are still dominated by summer tourism.

The tourism industry has reacted to the increasing demand for stereotypical winter activities by developing new winter activities such as dog-sledging and Northern Lights watching and by offering artificial winter activities on a year-round basis. The Icehotel 365 in Jukkasjärvi and the Kemi SnowExperience 365 are recent examples of this trend. This leads to a situation where the potential of other seasons remains unrealized and where, quite stereotypically, the permanent availability of winter has become the ultimate strategic priority for some tourism stakeholders.

This does not, of course, reflect the true conditions of the European North and the Arctic. Instead it can be argued that Arctification also entails the industrial production of a touristic Arctic (analogously to Saarinen's (2005) "touristic wilderness"). This reflects a product meeting the demand of a global tourist market rather than showing the realities of life and the environment in the Arctic North. 


\title{
5. Global environmental change
}

\begin{abstract}
In this chapter, the implications of global environmental change for seasonality are presented. Global environmental change has major impacts on the Arctic environment and societies, including the tourism industry, its operations, and seasonality. Tourism is a highly climate-dependent industry, and in the near future (as well as the present), changes in environment will have both negative and positive outcomes for the industry. In general, Arctic tourism is characterized by high seasonality and the estimated effects of climate change will likely deepen the seasonality aspects of tourism in the Arctic. In order to reduce the negative aspects and gain from the new emerging possibilities of a changing environment and seasonal changes, there is a need to expand and diversify the products and markets. However, this needs to be managed in a responsible way given the fragile and vulnerable Arctic environment and its communities.
\end{abstract}

\subsection{Introduction}

In Arctic Europe, global environmental change is predicted to produce stronger effects and proceed faster than across the rest of the continent. It is thus a critical topic, especially in destinations where attractions, activities and the basic structure and seasonality of tourism products and services are very much related to, and/or dependent on, natural resources with predictable environmental conditions. The changing climate will especially influence the environment and environmental conditions, the impacts of which will then be reflected to the tourism industry and tourists themselves in many diverse ways. As tourism is a highly climate-dependent industry it is possible that these changes will have a great influence on tourism seasons (Amelung et al., 2007) both directly (e.g., by changing the current attractions based on the occurrence of snow) and indirectly (e.g., by impacting on the annual rhythm of reindeer herders and farmers or socialization to winter tourism activities such as crosscountry skiing).

What also emphasizes the importance of global environmental change in the Arctic is the sensitivity of the environment (in both northern Europe and Canada). Stephen (2018) acknowledges the vulnerability of both ecological and sociocultural environments, underlining also the diversity in the region: low populations and long distances in contrast to bustling urban areas. On the ecological side, nature is often fragile and harsh conditions prevail, and the production of tourism services must be done by exercising extreme caution. Thus, even small-scale changes in the environment may lead to less tourism-tolerant conditions in the Arctic. On some occasions, however, 
the tolerance/resistance of the natural environment to tourism activities may also improve and become more resilient across seasons (see Hall, Prayang, \& Amore, 2018; Lew \& Cheer, 2018). In tourism, resilience refers to a tourism system, on a destination scale, which has the adaptive capacity and resources to absorb change and disturbance in the socio-ecological environment and sustain itself by transforming via learning and innovation (Saarinen \& Gill, 2019). Thus, the socio-ecological context of the tourism system has a great impact. In relation to sociocultural issues, for example, countries and regions differ in terms of livelihoods, infrastructure, accessibility, demographics, etc., which has implications for the magnitude and significance of the impacts brought by environmental changes. When the starting points and scenarios for future changes in the Arctic differ remarkably between regions the outcomes can vary a lot, which decreases the predictability of the impacts from a touristic perspective.

Many tourist destinations base their attractiveness on their climatic and related weather conditions during the peak seasons. However, the seasonality of tourism in the Arctic from the perspective of global environmental change has not been studied extensively. Current research literature mostly approaches climate change and its influence on (nature-based) tourism activities in Swedish and Finnish Lapland and in northern Norway while Greenland and Iceland have only lately started to attract researchers' interest from that perspective. Thus, few research data /results are available. In Canada, climate change research in relation to tourism has tended to focus on specific locations (Churchill, Manitoba), species (polar bears) or sectors/activities (cruise ships) (see Dawson, Maher, \& Slocombe, 2007; Dawson et al., 2009).

\subsection{Seasons will change - what are the implications for seasonality?}

In tourism, the Arctic region is characterized by the high seasonality of activities and tourism flows (Hall \& Saarinen, 2010b, p. 454). Seasonality is often regarded negatively in tourism studies and destination development literature. In the Arctic, however, it also creates the potential for attractiveness by providing a diverse base for Arctic tourism products and experiences (Johnston, 2011; Viken, 2013); however, these remain rather unpredictable. Due to the processes and impact of global environmental change, this seasonal diversity and its structure are under pressure. Indeed, many studies concerning the implications of global environmental change refer to climate change as a starting point for negative future prospects. Climate change is currently considered the most powerful driver of change, especially in terms of temperatures and precipitation patterns, as well as the occurrence of extreme weather events having shifted vastly during the last 50 years, with future scenarios predicting even faster changes (AMAP, 2012; Vikhamar-Schuler et al., 2016). The influence of changing climate on tourism, compared to global environmental change, is also more direct and to some extent easier to predict, as analogues of past climate events provide useful information for understanding and coping with future conditions (Dawson, Scott, \& McBoyle, 2009; Tervo-Kankare, 2012). 
In general, the Arctic region is expected to warm relatively fast, especially during winters. Precipitation increases will also be focused on winter periods. These will lead to a shortening of the snow season, changing snow patters, thawing of permafrost, decreasing snow and ice cover (including mountain areas and glaciers), and, in general, drier summer landscapes (AMAP, 2012). In tourism destinations relying heavily on nature's seasons as attractions and as the basis for key activities this will have dramatic impacts on visitation levels and thus on the overall seasonality of tourism. Since the changes will be more extreme during winters, the destinations with high snow- and icedependent winter seasons will be affected most. The winter season is getting shorter, and thus summers may be prolonged a bit, while spring and autumn either lengthen or stay the same depending on the summer season. Obviously, despite changes in temperature and precipitation, the amount of light or darkness will remain the same, both limiting and enabling certain tourist activities in future. All this will naturally influence those tourism activities and destinations that rely heavily on the Arctification of the northern environment (an amplification or duplication of the problem).

Thus, some of the crucial questions are related to the potential implications of environmental change for different kinds of tourism products. How does this global phenomenon contribute to the seasonality of tourism in the Arctic? Research conducted so far has mostly focused on those forms of tourism that are under the most acute and severe threat: snow- and ice-based forms of tourism, i.e. skiing and other snowdependent tourism (snowmobiling, skating, snow buildings, etc.), glacier tourism and Christmas tourism (in its current winter tourism form). These modalities will face (and are already facing) problems due to shortening of the snow season (Brouder \& Lundmark, 2011; Demiroglu, Dannevik, \& Aall, 2018; Falk \& Hagsten, 2017; Furunes \& Mykletun, 2012; Moen \& Fredman, 2007; Tervo, 2008; Tervo-Kankare et al., 2013; Tervo-Kankare, Kaján, \& Saarinen, 2018). Mostly, this has meant delays in the starting of the season with implications for hiring seasonal workers and making profit within a shorter period.

Arctic summer tourism is also changing, but maybe to a lesser extent in relation to seasons - changing flora and fauna have raised some concerns (Nilsson \& Gössling, 2013; Tervo-Kankare et al., 2018; Tiller et al., 2017). However, their significance to seasonality has not yet been discussed or studied in detail. Cruise tourism and polar bear tourism have also been discussed in the Canadian context (Dawson, Stewart, \& Scott, 2010), and the results may be applied to northern Europe as well, the further opening up of Arctic waterways being one important aspect. In general, there are expectations that winters and summers will change considerably, the differences between seasons fading and the autumn and spring seasons becoming transition seasons, which may support the development of year-round tourism. This view was also supported in the workshop realized in October/November 2018 and in the VAE project's survey. However, there also remains uncertainty, especially among the tourism operators who say that the "business is becoming more scared because of climate change" (participant in focus group 2).

To offset this anxiety, but also to showcase some benefit from the positive impacts of a changing environment, adaptation is needed. The current adaptation methods mainly focus on the diversification and development of new tourism products (e.g., less 
snow-dependent) and locations (activities transferred to the north); increasing yearround tourism (thereby relating to seasonality); and maintaining the current conditions, for example utilizing artificial snow. In terms of global environmental change, the last adaptation in particular can be considered a contradictory solution: even though artificial snow helps to sustain and prolong the current seasons, it has environmental consequences that accelerate global environmental change. Thus, it cannot be a sustainable long-term solution.

This means that overcoming the negative influence of a changing climate very much leans on the success of destination governance (Bramwell, 2011). As noted by Baggio, Scott, and Cooper (2010, p. 52), "the governance system may be considered as the tool by which the destination adapts to change". Under the current situation of global environmental change there is an urgent need for better destination governance (Saarinen \& Gill, 2019), including operational product development, diversification, innovation and marketing, and also adaptation and mitigation measures. These, in turn, relate to the development of year-round tourism, e.g., in the form of snowindependent tourism activities. Year-round tourism is something that many tourism destinations are hoping to develop, and thus the estimated and ongoing impact of climate change (and related global environmental change) as forcing mechanisms for technological and social innovations can be seen as positive: it gives an extra boost to this development. Ski resorts, in particular, adapt well in this regard, utilizing slopes/trails, chairlifts, and other infrastructure for mountain biking and then shifting activity start/end dates based on what larger "season" is available.

Despite the possible positive forcing impact of climate change on year-round tourism development, several questions remain open. The issues that were raised during the workshop focused in particular on the current nature of tourism destinations and activities, the uncertainty concerning future conditions and the changing customer profiles. Unfortunately, not much research has been done on most of these topics yet.

The unpredictability of (weather) conditions may affect seasons in two ways: in the short term, it was mostly considered to affect tourism expenditure by shifting the location to where money is spent:

On occasions where products are bought on the spot (40\% in certain Lappish destinations), bad conditions lead to no buying and money is used elsewhere - this may be a threat but also a possibility, if the destination is diversified enough. (Participant in focus group 2)

This kind of development has been identified in research studies as well: e.g., in TervoKankare et al. (2018) the authors suggested that diversified destinations (opportunities for shopping, both indoor and outdoor activities, restaurants and cafes, etc.) are coping better with the changing climate. In the long term, this unpredictability may start to influence the seasons and seasonality, especially if the images of the destinations change permanently. The unpredictability of weather and increasing cloudiness also influence and challenge Northern Lights tourism, which seems to be gaining more popularity both according to the workshop discussions and the VAE results (more than two-thirds of the enterprises in the survey were currently offering Northern Lights activities, and this was also mentioned as one potential activity to gain growth for the current low season). 
Environmental change inevitably means changes in nature as well. The focus group discussions pondered upon the future of, for example, reindeer (environmental change will influence their seasonal rhythms and the possibilities for tourism) and other elements of nature. The arrival of new species (flora and fauna) was also discussed, but not much is known about their potential (can new activities be built on them or are there negative impacts for tourism?). Only a few studies have so far touched upon this topic, e.g., Tiller et al. (2017) on the jellyfish entering Norwegian fjords and Nilsson and Gössling (2013) on algae blooms in the Baltic sea and their negative impacts on waterrelated tourism activities. What also raised concern during the focus group discussions was the sensitivity of nature: with climate and environmental change proceeding, it is possible that the environment's resilience will change - some regions may become more tolerant to nature-based activities, while in others, the impact may be the opposite. This very important issue relates to carrying capacity and sustainability in general and may pose a major challenge in the development of all-year nature-based tourism activities in the Arctic region.

\subsection{Will climate change affect tourist behaviour?}

As noted, the effects of global climate change on seasonality will depend greatly on the adaptive capacity and resilience of tourism destinations and the Arctic societies, in general, that choose to host tourists. In addition, tourists also have the agency to react to the impact of climate change and/or the drivers of the change. The former refers to reactions and potential adaptation to changing conditions in destinations and seasonality, while the latter is based on transforming awareness and knowledge, values and priorities in relation to climate change and its mitigation measures in terms of tourist mobility and consumption. Both aspects will have substantial implications for spatial and temporal redistribution of tourism activities (see Amelung et al., 2007). This type of behaviour change is discussed by Maher and others across the Arctic (and Antarctic) (see Maher, 2010; Maher, Johnston, Dawson, \& Noakes, 2011).

Previous research has indicated several ongoing and potential impacts of environmental change on tourist behaviour in the Arctic. For example, while the Arctic areas of Europe and North America will gain a competitive advantage in snow-based winter tourism in the next few decades compared to destinations located in central Europe or southern parts of the Nordic countries, a key challenge is maintaining the customer base for winter activities in the tourist-generating regions. This concern was also presented in the workshop discussions: due to shortening or lacking snow periods in the current tourist-generating regions, new generations will not necessarily learn to ski and perceive the attractiveness of such activities, for example, which channels their future tourism demand toward alternative destinations. Thus, from the perspective of Arctic tourism destinations and their snow-based winter tourism attractiveness, there is a need to create and support artificial environments for winter tourism socialization in the current tourist-generating regions and to expand the tourist markets in future. 
This expansion of the markets includes an integration of new major tourist-generating regions for the development of snow-based winter tourism. But it also involves a general market change, whose process is visibly ongoing in relation to Chinese and Indian markets, and the development of new major products for other than traditional winter seasons. One of the potential major future products is based on Arctic cruise tourism, as the warming effects of climate change in the form of shrinking ice cover may open up new routes and/or expand the current operational season for cruises (Hall \& Saarinen, 2010c; Lück, Maher, \& Stewart, 2010). Some scholars, however, are less optimistic regarding the future potential of Arctic waters for cruise tourism purposes (Stewart et al., 2007). During the workshop and also in previous research (TervoKankare et al., 2018), the industry representatives referred to the potential of the summer season to attract increasing numbers of tourists escaping the increasingly hot summers in southern Europe. To date, however, this anticipated development is not visible and cannot be verified from tourism statistics.

A rapidly changing Arctic environment is also expected to create so-called "last chance tourism". In general, last chance tourism is based on a tourism market focusing on witnessing and experiencing a place or phenomenon before it disappears (Dawson et al., 2011; Hall \& Saarinen, 2010a; Lemelin et al., 2010). Certain glaciers, for example, have already received increasing tourist attention due to visible receding of the glacier, and recently the media has highlighted the fast melting of glaciers in Greenland. These kinds of processes and images call for greater responsibility in terms of tourism products and tourists' consumption and the development of context-specific sustainable tourism governance models for the Arctic tourism characterized by a fragile natural environment and vulnerable local communities.

\subsection{Security issues}

The commercial nature of tourism in Arctic Europe is often seen to be safe since the peripheral areas offer a terrorism- and crime-free environment for tourists. However, there are several issues related to the internal safety of tourism services that should be given more attention when environmental conditions change. The safety of naturebased tourism services depends on different factors: for example, a snowmobile excursion includes customers seeking pleasure, guides working to achieve different needs and goals, and environmental factors setting the conditions for the excursion (Rantala \& Valkonen, 2011). In order to be able to carry out the excursion completely safely, the guide must take into account the infrastructure and technology, such as the condition of the routes and constant changes in weather forecasts.

During the workshop, we were presented with examples from Cape Breton of the changing conditions on the routes due to climate change - rainfall in winter seasons can suddenly destroy snowmobile routes, and similarly, heavy snowfalls in summer can cause problems. Examples of similar events, such as rain-on-snow (ROS) events, followed by ground ice accumulation have also raised concern in the European Arctic by leading to icy roads and airport closures (Vikhamar-Schuler et al., 2016). 
Changing environmental conditions mean that not all traditional knowledge concerning safety holds true anymore and new procedures may be needed. There will be more icy roads (which are already a problem in Finnish Lapland, often at the beginning of the winter season), and icy paths may lead to more tourists being injured, which can overburden the local health-care and fire and rescue services. Due to changing snow and permafrost, the risks of snow avalanches and landslides may also increase, which is a topic that has not yet been approached in research.

In addition, the inexperience of both the customers and seasonal workers in acting with changing local environmental conditions further increases the complexity of the issue of safety. Since holiday decisions are made at short notice and the booking of trips is made easier, tourists are probably less aware of, and less prepared for, the specific features of destinations they will go to and activities they will participate in. Due to the diversification of clientele, the skills and tacit knowledge of the guides becomes emphasized in relation to articulating risks to the diverse tourist groups, including, among others, increased numbers of senior tourists (Rantala et al., 2018). This can be challenging if the seasonal guides are not sufficiently well acquainted with the local environment and the changing conditions. In addition, recent research has indicated that leadership and convenience are becoming very important in destinations, illustrating that not only should emphasis be placed on what the guide or entrepreneur does, but increasingly the whole destination should be convenient for the tourist (Rantala et al., 2018). This further highlights the multiplicity of skills needed from everyone living and working at the destination and the increased need for diverse infrastructure. Hence, further research is needed to examine how to develop safe and convenient destinations without turning them into stereotypical resorts that all resemble each other.

\subsection{Conclusion}

Global environmental change has major impacts on the Arctic environment and societies, including the tourism industry, its operations and seasonality. Tourism is a highly climate-dependent industry, and in the near future (as well as the present), changes in environment will have both negative and positive outcomes for the industry. In general, Arctic tourism is characterized by high seasonality, and the estimated effects of climate change will most probably deepen the seasonality aspects of tourism in the Arctic. In order to reduce the negative aspects and gain from the new emerging possibilities of a changing environment and seasonal changes, there is a need to expand and diversify the products and markets. However, this needs to be managed in a responsible way given the fragile and vulnerable Arctic environment and its communities. Thus, in the overall context of global climate change and the adaptation and mitigation needs it creates, the key aspect of Arctic tourism development is sustainable tourism governance in future. Arctic tourism destinations are far away from the main tourist markets, which causes extra mobility with major emissions and thus extra pressures for sustainability governance on a destination scale. 


\section{Conclusion and recommendations}

\subsection{Challenges and advantages related to seasonality of Arctic tourism}

The seasonal nature of tourism is undergoing considerable change across the northern polar region, and is increasingly garnering the attention of tourism destination planners and economic development strategists at all levels, tour operators and the diverse businesses that significantly depend on tourism, and the host communities and residents who negotiate tourism's potential to have both positive and negative impacts. The main aim of this report has been to understand in what contexts and from what perspectives the seasonality of tourism is problematized and interpreted as a problem in the Arctic. Based on a collaborative analysis process, we have identified four main perspectives that should be taken into account when trying to understand the challenges related to the seasonality of tourism in the Arctic.

First, from the point of view of the communities, seasonality is problematized when it leads to serious negative impact to local people - when their events and cultures are increasingly being enhanced to provide entertainment during the peak season; when capitalist economy logic contradicts the rhythms of lifestyle entrepreneurs; when communities and environments need to face the pressures of peak season; and when outmigration and closed facilities and services interrupt - or enhance - the sense of place during the low season. Second, from the perspective of the workforce and employment, seasonality impacts on the image of tourism as a sector that can offer rewarding jobs and strengthens the image of tourism employment as precarious and low-skilled; seasonality hinders the hiring of people with skills and capacities, and attracts transient workers often characterized by a lack of commitment to place, or at least to a specific employer in a place. In turn, retention issues lead to the high costs associated with the persistent need to train new employees. Seasonality can determine the type and amount of investments made in places by government and municipalities - for example, in the form of housing. Third, there are global processes that alter the problems related to seasonality, such as Arctification, which reinforces the images of the Arctic as a cold and snowy destination, implies a neglect of the distinct environmental seasons of the North and hinders the development of a communitybased cultural and creative tourism. Finally, a fourth perspective relates to the estimated effects of climate change, which are likely to deepen the seasonality aspects of tourism in the Arctic and alter the course of an already sensitive region, along with its capacity for building resilience.

Alongside problem-oriented perspectives, seasonality can also be defined in positive terms: for example, the advantages of shaping narratives and experiences that rely on the attractiveness of having distinct Arctic seasons. Accordingly, the annual life 
cycles and rhythms of places, communities and environments form the bases for lifestyle, small-sized and indigenous entrepreneurs, and for them, seasonality can be a necessity. Seasonality also enables local communities "to take a break" from tourists and from the impact that tourists have on the sense of place in the community during the high season(s). Furthermore, seasonality can be seen in positive terms when it enables people to move and travel around for the seasonal work that currently characterizes much of the tourism employment on offer. The mobile nature of tourism work attracts younger people to transient, versatile and temporary adventures in peripheral areas. Thus, and inadvertently perhaps, the tourism sector is also an unacknowledged training ground for skills development and knowledge building in customer service for a number of other seasonality-oriented employment sectors (e.g., mining, forestry, road construction). In addition, tourism activities in Arctic Europe are firmly based on landscape and on seasonal characteristics - for example, the turn towards winter activities has implied a greater significance of seasonal landscapebased experiences. The new winter activities require service infrastructure and touristic services and thus provide greater opportunity for economic revenue.

The development of year-round tourism can lead to substantial growth of tourism. The key challenges surfacing along with a substantial growth of tourism, as a result of developing new seasons or year-round tourism, relate to handling the pressures of the peak season, which local communities and environments need to face. If the peak season is too strong, the communities will not wish to have year-round tourism, even though the aim would be to balance the seasonality in the long run. In addition, the growth of tourism into new seasons may prevent local actors from adapting to revised community rhythms and altered annual place cycles (e.g., impinge on events meant for community building and not for visitors that occur during months when there is little or no tourism). Furthermore, the sociocultural and ecological impacts of year-round tourism need to be estimated, because of the diversity of the Arctic region - there exist both peripheral areas and bustling urban areas. Hence, the needs of each specific community should be taken into account by applying community-first planning approaches - tourism should be for and with the community but not living off it. There are no general solutions available that would fit all.

The possibility of offering year-round and higher-quality employment forms one of the key opportunities related to the substantial growth of tourism due to developing new seasons (or year-round tourism). For locally owned companies in particular there is an urgent need for solutions regarding how to keep skilled employers. In addition, the development of year-round tourism can help the locally owned medium-sized and larger companies to compete with externally owned companies and prevent the transfer of industry ownership from local stakeholders to international investors (and furthermore prevent situations that entail competition through lower price levels). Furthermore, year-round tourism can bring resources to address environmental issues and to enhance the quality of the infrastructure.

Overall, year-round tourism in the context of Arctic Europe in future could consist of approximately 9-10 months of profitable business, which would leave space for a recovery season. However, through engaging the communities in tourism development 
and through caring for the environment, and by recognizing the specific characteristics of local contexts and global processes, such a sustainable form of tourism could be developed within which a recovery season might not be needed. In order to develop a thriving and sustainable tourism sector in Arctic Europe the following considerations should be addressed: adopting community-first planning; enhancing local business and tourism resources ownership -including sociocultural-oriented resources, for instance, festivals or indigenous culture-based attractions, and the utilization of new local innovative integrations of nature and culture in tourism; labour and employment issues; creating strategies to reduce labour precarity associated with tourism; educating travellers about sustainable Arctic ways of living, which are also responsible for how lifestyle entrepreneurship is expressed in the Arctic; enhancing urban Arctic tourism opportunities; utilization of the diverse distinct seasons existing in the Arctic; recognizing global environmental change; and committing to sustainable transportation.

In their study 20 years ago, Baum and Hagen (1999) identified four initiatives to counter sustainability in northern tourism destinations (events, market diversification, product diversification, and structural responses such as public sector incentives to maintain access to facilities and alterations in the labour market environment). In the report at hand, the aim has been to tackle the issues of seasonality comprehensively. We have hoped to provide information that can help in planning and developing policies that acknowledge that tourism development is deeply integrated in wider social, political and material processes. Hence, tourism should be considered an aspect of societal development and world making, instead of seeing it as a separate sphere in itself. This means, for example, recognizing how the development of year-round tourism is intertwined with the process of Arctification, which reinforces the image of a cold and harsh region empty of people and makes the creative development of communities difficult - a development that would recognize the possibilities related to new naturecultures and distinctive seasonal features of each region. In addition, the implications of the global environmental change for seasonality currently form an issue that needs to be addressed. Hence, the smart and responsible way to approach the seasonality of tourism managerially is to think first about the communities and the sensitive environment.

Next, a summary of the findings is formulated as recommendations that will link the development of tourism more closely to the development of sustainable Arctic societies. 


\subsection{Recommendations}

- Approach seasonality from a local community perspective, as long-term sustainable development of Arctic tourism relies on engaging in community development and caring for local environments. More specifically, this approach implies that:

- The framework for dealing with seasonality in management and policymaking at regional and national levels should consider contextually specific situations where year-round tourism may constitute a problem and/or an opportunity;

- Spatially sensitive strategies should be augmented with a view to increasing tourism in communities that are peripheral to core areas in the periphery and their tourism (e.g. peripheral to Reykjavik, Iceland).

- Strengthen the image and appreciation of tourism as an economic activity and provider of valuable and fairly compensated employment (SDG no. 8). This could also support positively integrating tourism into the social fabric of Arctic communities. Specifically, this strategy would also:

- Clarify the different career paths that exist within tourism (e.g., service, economic and/or community planning and development, destination promotion);

- Increase and promote the value and status of tourism-related employment (e.g., create strategies and campaigns that challenge the embedded definitions of tourism employment as "entry-level low-paying positions");

- Create ways to celebrate the fact that many young people make their way through university while gaining lifelong and transferable professionalism and other skills while working in this sector;

- Enhance training, education and mentorship opportunities;

- Focus on raising the competencies in the "local" labour pool;

- Work with stakeholders in fighting cheap labour use (social dumping) and labour precarity in tourism.

- Establish and implement regulatory and legislative frameworks that reflect and support mobile and dynamic tourism economies, which would in turn strengthen the destination communities (i.e. where tourism takes place):

- Create support systems for small and micro/nano-sized tourism companies for raising the level of competitiveness (innovation). It is important to recognize the different needs and possibilities of companies in tourism and therefore flexible support is crucial;

- Create nationwide tourism policy initiatives that recognize regional differences and the diversity of companies within the sector;

- Introduce a mechanism to ensure that income tax paid by seasonal workers stays within the community where they are working. 
- Balance the demand in the high seasons with increased efforts to develop products during emerging seasons. This could also help stabilize access to the labour force:

- Improve the knowledge content and service aspects of nature- and culturebased activities;

- Create tourism offerings during other seasons;

- Promote other seasons to high-season tourists.

- Develop high-season tourism based on the local community perspective and with diverse images representing a variety of Arctic meanings and experiences:

- Avoid stereotypical production and marketing of winter tourism that reinforces the Arctification process and the image of the Arctic as cold, snowy and empty of people;

- Support development of new local innovative integrations of nature and culture and development of tourism based on these.

- Develop adaptive capacity and proactive resilience-oriented measures that will positively influence environmental change:

- Improve awareness of global change and its local consequences in Arctic tourism destinations;

- Alongside tourism season diversification, diversify markets and tourism experiences.

- Develop sustainable governance models in Arctic tourism destination development:

- Strengthen the connections made between sustainable governance initiatives and discussions as they are occurring in the Arctic with tourism development processes, including pan-circumpolar and East to West network building, and knowledge creation and sharing;

- Utilize sustainable and responsible tourism initiatives within the framework of the United Nations Sustainable Development Goals (SDGs);

- Broaden the knowledge base and research produced and utilized for developing tourism-related innovations. 


\section{References}

AMAP. (2012). Arctic climate issues 2011: Changes in Arctic snow, water, ice and permafrost. SWIPA 2011. Overview Report.

Amelung, B., Nicholls, S., \& Viner, D. (2007). Implications of global climate change for tourism flows and seasonality. Journal of Travel Research, 45, 285-296.

https://doi.org/10.1177/0047287506295937

Atvinnuvega- og nýsköpunarráđuneytið. (2015). Vegvísir i ferðapjónustu. Reykjavík Atvinnuvega- og nýsköpunarráduneytið.

Aurora Winter Festival (2018). Retrieved from https://www.tourismvancouver.com/event/aurora-winter-festival/18806/

Árnason, T., \& Welling, J.T. (forthcoming). Winter tourism and seasonality in Iceland. In U. PröbstlHaider, H. Richins, \& S. Türk (Eds.), Winter tourism. Wallington, UK: CABI Publications.

Baggio, R., Scott, N., \& Cooper, C. (2010). Improving tourism destination governance: A complexity science approach. Tourism Review, 65(4), 51-60.

https://doi.org/10.1108/16605371011093863

Baum, T. (2007). Human resources in tourism: Still waiting for change. Tourism Management, 28, 1383-1399. https://doi.org/10.1016/j.tourman.2015.02.001

Baum, T., \& Hagen, L. (1999). Responses to seasonality: The experiences of peripheral destinations. The International Journal of Tourism Research, 1, 299-312.

Baum, T., Kralj, A., Robinson, R. N. S., \& Solnet, D. J. (2016). Tourism workforce research: A review, taxonomy and agenda. Annals of Tourism Research, 60, 1-22. doi:http://dx.doi.org/10.1016/j.annals.2016.04.003

Bodén, B., \& Rosenberg, L. (2004). Kommersiell turism och lokal samhällsutveckling: En studie av sex svenska fjälldestinationer. Östersund: Etour.

Bramwell, B. (2011). Governance, the state and sustainable tourism: A political economy approach. Journal of Sustainable Tourism, 19, 459-477.

https://doi.org/10.108o/og669582.2011.576765

Brouder, P. (2012). Creative outposts: Tourism's place in rural innovation. Tourism Planning \& Development, 9, 383-396. https://doi.org/10.1080/21568316.2012.726254

Brouder, P., \& Lundmark, L. (2011). Climate change in Northern Sweden: Intra-regional perceptions of vulnerability among winter-oriented tourism businesses. Journal of Sustainable Tourism, 19, 919-933. https://doi.org/10.1080/og669582.2011.573073

Butler, R. W. (1998). Rural recreation and tourism. In B. Ilberry (Ed.), The geography of rural change (211-232). Harlow: Longman.

Dawson, J., Johnston, M. E., Stewart, E. J., Lemieux, C., Lemelin, R. H., Maher, P., \& Grimwood, B. (2011). Ethical considerations of last chance tourism. Special issue on ethics and ecotourism. Journal of Ecotourism,10, 250-265. https://doi.org/10.1080/14724049.2011.617449

Dawson, J., Maher, P. T., \& Slocombe, D. S. (2007). Climate change, marine tourism and sustainability in the Canadian Arctic: Contributions from systems and complexity approaches. Tourism in Marine Environments, 4(2-3), 69-83. https://doi.org/10.3727/154427307784772057

Dawson J., Scott, D., \& McBoyle, G. (2009). Climate change analogue analysis of ski tourism in the northeastern USA. Climate Research, 39, 1-9. doi: https://doi.org/10.3354/croo793

Dawson, J., Stewart, E., \& Scott, D. (2010). Climate change and polar bear viewing: A case study of visitor demand, carbon emissions and mitigation in Churchill, Canada. In C. M. Hall \& J. Saarinen (Eds.), Tourism and change in polar regions: Climate, environment and experiences (89-103). Abingdon: Routledge. 
de la Barre, S. (2013). Wilderness and cultural tour guides, place identity and sustainable tourism in remote areas. Journal of Sustainable Tourism, 21, 825-844.

https://doi.org/10.108o/og669582.2012.737798

de la Barre, S. (in press). Creative Yukon: Finding data to tell the cultural economy story. In K. Scherf (Ed.), Creative tourism and sustainable development in smaller communities. Calgary: University of Calgary Press.

Demiroglu, O. C., Dannevig, H., \& Aall, C. (2018). Climate change acknowledgement and responses of summer (glacier) ski visitors in Norway. Scandinavian Journal of Hospitality and Tourism, 18, 419-438. https://doi.org/10.1080/15022250.2018.1522721

Destination Canada (2019). Retrieved from https://www.destinationcanada.com/en/news/bestyear-ever-canadian-tourism-208m-arrivals

Dodds, K., \& Nuttall, M. (2016). The scramble for the poles: The geopolitics of the Arctic and Antarctic. Cambridge: Polity Press.

Engeset, M. G., Hull, J. S., \& Velvin, J. (2016). Promoting service excellence for tourist destinations. International Journal of Culture, Tourism and Hospitality Research, 10, 440-454. https://doi.org/10.1108/IJCTHR-08-2015-0097

Falk, M., \& Hagsten, E. (2017). Climate change threats to one of the world's largest crosscountry skiing races. Climatic Change, 143, 59-71. https://doi.org/10.1007/s10584-017-1992-2

Ferðamálastofa Íslands. (2018). Tourism in Iceland in figures. Retrieved from https://www.ferdamalastofa.is/static/files/ferdamalastofa/Frettamyndir/2018/oktober/tourism -in-iceland-2018.pdf

Fredman, P., Emmelin, L., Heberlein, T. A., \& Yuorio, T. (2001). Tourism in the Swedish mountain region. In B. Sahlberg (Ed.), Going north: Peripheral tourism in Canada and Sweden (121-463). Östersund: Etour.

Furunes, T., \& Mykletun, R. J. (2012). Frozen adventure at risk? A 7-year follow-up study of Norwegian glacier tourism. Scandinavian Journal of Hospitality and Tourism, 12, 324-348. https://doi.org/10.1080/15022250.2012.748507

Government of Nunavut. (2012). Tunngasaiji: A tourism strategy for Nunavummiut. Retrieved from: https://www.gov.nu.ca/sites/default/files/tourism-strategy-en-2-aug21-web.pdf

Granås, B. (2018). Destinizing Finnmark: Place making through dogsledding. Annals of Tourism Research, 72, 48-57. https://doi.org/10.1016/j.annals.2018.05.005

Grenier, A. A. (2007). The diversity of polar tourism: Some challenges facing the industry in Rovaniemi, Finland. Polar Geography, 30(1-2), 55-72. https://doi.org/10.1080/10889370701666622

Gunnarsdóttir, G. P., \& Jóhannesson, G. T. (2014). Weaving with witchcraft: Tourism and entrepreneurship in Strandir, Iceland. In A. Viken \& B. Granås (Eds.), Destination development in tourism: Turns and tactics (95-112). Farnham: Ashgate.

Gössling, S., Scott, D., Hall, C. M., Ceron, J., \& Dubois, G. (2012). Consumer behaviour and demand response of tourists to climate change. Annals of Tourism Research, 39, 36-58. https://doi.org/10.1016/j.annals.2011.11.002

Hall, C. M., Prayang, G., \& Amore, A. (2018). Tourism and resilience: Individual, organizational and destination perspectives. Bristol: Channel View Publications.

Hall, C. M., \& Saarinen, J. (2010a). Last chance to see? Future issues for polar tourism and change. In C. M. Hall \& J. Saarinen (Eds.), Tourism and change in the polar regions: Climate, environment and experience (310-310). London: Routledge.

Hall, C. M., \& Saarinen, J. (2010b). Polar tourism: Definitions and dimensions. Scandinavian Journal of Hospitality and Tourism, 10, 448-467. https://doi.org/10.1080/15022250.2010.521686

Hall, C. M., \& Saarinen, J. (2010c). Tourism and change in the polar regions: Introduction definitions, locations, places and dimensions. In C. M. Hall \& J. Saarinen (Eds.), Tourism and change in polar regions: Climate, environments and experiences (1-41). Abingdon: Routledge. 
Halpern, N. (2008). Lapland's airports: Facilitating the development of international tourism in a peripheral region. Scandinavian Journal of Hospitality and Tourism, 8, 25-47.

https://doi.org/10.1080/15022250801987762

Hannam, K., Sheller, M., \& Urry, J. (2006). Editorial: Mobilities, immobilities and moorings. Mobilities, 1, 1-22. https://doi.org/10.1080/17450100500489189

Hansson, H. (2015). Arctopias: The Arctic as no place and new place in fiction. In B. Evengård, J. Nymand Larsen, \& Ø. Paasche (Eds.), The new Arctic (69-77). Cham: Springer.

Hansson, H. (2018). The Arctic in literature and the popular imagination. In M. Nuttall, T. R. Christensen, \& M. Siegert (Eds.), The Routledge handbook of the polar regions (71-82). London: Routledge.

Haraway, D. (1997). Modest_Witness@Second_Millennium.

FemaleMan@_Meets_OncoMouse ${ }^{\mathrm{TM}}$ : Feminism and technoscience. London: Routledge.

Heimtun, B. (2016). Emotions and affects at work on Northern Lights tours. Hospitality \& Society, 6, 223-241. https://doi.org/10.1386/hosp.6.3.223_1

Heimtun, B., Jóhannesson, G. T., \& Tuulentie, S. (2014). Northern lights tourism in Iceland, Norway and Finland. Alta: UiT, The Arctic University of Norway.

Heimtun, B., \& Viken, A. (2015). Nordlysturismen - en institusjonelt betinget utvikling? In A. Viken (Ed.), Turisme: Destinasjonsutvikling. Oslo: Gyldendal Norsk.

Hollinshead, K. (1998). Disney and commodity aesthetics: A critique of Fjellman's analysis of 'distory' and the 'historicide' of the past. Current Issues in Tourism, 1, 58-119.

https://doi.org/10.1080/13683509808667833

House of Lapland. (2018). Numbers to back up the claims. Infographics. Retrieved from https://www.lapland.fi/fi/business/faktat-ja-tilastot/.

Härkönen, E., Jokela, T. \& Yliharju, A.-J. (2014). Snow design from Lapland: Initiating cooperation. (Publications of the Faculty of Art and Design of the University of Lapland, Series C, Overviews and discussion.) Retrieved from http://urn.fi/URN:ISBN:978-952-484-738-4

ITAC. (2018). Indigenous Tourism Association of Canada. Retrieved from https://indigenoustourism.ca/en/embrace-winter-canada-indigenous-experiences/

Jacobsen, J. K. S. (1997). The making of an attraction. Annals of Tourism Research, 24, 341-356. https://doi.org/10.1016/s016o-7383(97)80005-9

Jóhannesson, G. T., Huijbens, E. H., \& Sharpley, R. (2010). Icelandic tourism: Past directions future challenges. Tourism Geographies, 12, 278-301.

https://doi.org/10.1080/14616680903493670

Jóhannesson, G. T., \& Lund, K. A. (2017). Aurora Borealis: Choreographies of darkness and light. Annals of Tourism Research, 63, 183-190. https://doi.org/10.1016/j.annals.2017.02.001

Jóhannesson, G. T., \& Lund, K. A. (2018). Creative connections? Tourists, entrepreneurs and destination dynamics. Scandinavian Journal of Hospitality and Tourism, 18(sup1), S6o-S74. https://doi.org/10.1080/15022250.2017.1340549

Johnston, M. E. (2011). Arctic tourism introduction. In P. T. Maher, E. J. Stewart, \& M. Lück (Eds.), Polar tourism: Human, environmental and governance dimensions (17-32). Putnam Valley, NY: Cognizant Communication.

Jæger, K., \& Olsen, K. (2016). On commodification: Volunteer experiences in festivals. Journal of Tourism and Cultural Change, 15, 407-421. https://doi.org/10.1080/14766825.2016.1168827

Konu, H., Tyrväinen, L., Pesonen, J., Tuulentie, S., Pasanen, K., \& Tuohino, A. (2017). Uutta liiketoimintaa kestävän luontomatkailun ja virkistyskäytön ympärille - Kirjallisuuskatsaus. (Valtioneuvoston selvitys- ja tutkimustoiminnan julkaisusarja 45/2017.)

Kyyrä, S., \& Rantala, O. (2016). Disoriented travellers or disoriented destinations? An analysis of future travel trend studies for Visit Arctic Europe project. Unpublished report.

Lee, D., Hampton, M., \& Jeyacheya, J. (2015). The political economy of precarious work in the tourism industry in small island developing states. Review of International Political Economy, 22, 194-223. https://doi.org/10.1080/09692290.2014.887590 
Lemelin, H., Dawson, J., Stewart, E. J., Maher, P., \& Lück, M. (2010). Last-chance tourism: The boom, doom, and gloom of visiting vanishing destinations. Current Issues in Tourism, 13, 477493. https://doi.org/10.1080/13683500903406367

Lew, A. A., \& Cheer, J. (2018). Tourism resilience and adaptation to environmental change: Definitions and frameworks. Routledge: London.

Loftsdóttir, K. (2015). The exotic north: Gender, nation branding and post-colonialism in Iceland. NORA - Nordic Journal of Feminist and Gender Research, 23, 246-26o. https://doi.org/10.1080/08038740.2015.1086814

Loftsdóttir, K., Kjartansdóttir, K., \& Lund, K. A. (2017). Trapped in clichés: Masculinity, films and tourism in Iceland. Gender, Place \& Culture, 24, 1225-1242. https://doi.org/10.1080/og66369x.2017.1372383

Lück, M., Maher, P. T., \& Stewart, E. J. (Eds.) (2010). Cruise tourism in polar regions: Promoting environmental and social sustainability? London: Earthscan.

Lundgren, J. O. (1995). The tourism space penetration processes in northern Canada and Scandinavia: A comparison. In C. M. Hall \& M. Johnston (Eds.), Polar tourism: Tourism in the arctic and antarctic regions (43-61). Chichester: Wiley.

Lundgren, J. O. J. (2001). Canadian tourism going north: An overview with comparative Scandinavian perspectives. In B. Sahlberg (Ed.), Going north: Peripheral tourism in Canada and Sweden (13-45). Östersund: Etour.

MacCannell, D. (1976). The tourist: A new theory of the leisure class. New York: Schocken Books.

Maher, P. T. (2010). Cruise tourist experiences and management implications for Auyuittuq, Sirmilik and Quttinirpaaq National Parks, Nunavut, Canada. In C.M. Hall \& J. Saarinen (Eds.), Tourism and change in the polar regions: Climate, environments and experiences (119-134). Oxford: Routledge.

Maher, P. T., Johnston, M. E., Dawson, J. P., \& Noakes, J. (2011). Risk and a changing environment for Antarctic tourism. Current Issues in Tourism, 14, 387-399. https://doi.org/10.1080/13683500.2010.491896

Mair, H., \& Reid, D. G. (2007). Tourism and community development vs. tourism for community development: Conceptualizing planning as power, knowledge, and control. Leisure/Loisir, 31, 403-425. https://doi.org/10.1080/14927713.2007.9651389

Moen, J., \& Fredman, P. (2007). Effects of climate change on alpine skiing in Sweden. Journal of Sustainable Tourism, 15, 418-437. https://doi.org/10.2167/jost624.0

Müller, D. K. (2011). Tourism development in Europe's "last wilderness": An assessment of nature-based tourism in Swedish Lapland. In A. A. Grenier \& D. K. Müller (Eds.), Polar tourism: A tool for regional development (129-153). Montreal: Presses de I'Université du Québec.

Müller, D. K. (2015). Issues in Arctic tourism. In B. Evengård, J. Nymand Larsen, \& Ø. Paasche (Eds.), The new Arctic (147-158). Cham: Springer.

Müller, D.K. (2019). An evolutionary economic geography perspective on tourism development in the periphery: The case of Tärnaby/Hemavan in the Swedish mountains. In R. Koster \& D. Carson (Eds.), The exotic, the fringe and the boring bits in between: New perspectives on rural tourism geographies (137-157). Cham: Springer.

Müller, D. K., \& Pettersson, R. (2001). Access to Sami tourism in northern Sweden. Scandinavian Journal of Hospitality and Tourism, 1, 5-18. https://doi.org/10.1080/15022250127793

Müller, D. K., \& Viken, A. (2017). Toward a de-essentializing of indigenous tourism? In A. Viken \& D. K. Müller (Eds.), Tourism and indigeneity in the Arctic (281-289). Bristol: Channel View.

Nilsson, J. H., \& Gössling, S. (2013). Tourist responses to extreme environmental events: The case of Baltic Sea algal blooms. Tourism Planning \& Development, 10, 32-44. https://doi.org/10.1080/21568316.2012.723037

Nordic Council of Ministers. (2018). Arctic business analysis: Creative and cultural industries. Retrieved from http://norden.diva-portal.org/smash/get/diva2:1175681/FULLTEXTo1.pdf 
NWT. (2018). Tourism demand leads to non-stop Yellowknife-Vancouver flights renewed, Expanded for 2018-19. Government of Northwest Territories (Press release, August 8). Retrieved from https://www.gov.nt.ca/en/newsroom/news/tourism-demand-leads-non-stopyellowknife-vancouver-flights-renewed-expanded-2018-19

NWT. (2016). Towards a \$235 million NWT Tourism Industry 5-year NWT tourism marketing strategy (December). Government of Northwest Territories. Retrieved from https://members.spectacularnwt.com/sites/default/files/Five\%20Year\%20Marketing\%20Strat egy\%20\%282016\%29\%20\%20FINAL.pdf

Pedersen, K. \& Viken, A. (1996). From Sami nomadism to global tourism. In M. Price (Ed.), People and tourism in fragile environments (69-88). Chichester: John Wiley.

Penttonen, S. (2018). A good method of making money: Seasonal wilderness' guides wellbeing in Finnish Lapland. Unpublished master thesis. University of Lapland. Retrieved from http://urn.fi/URN:NBN:fi:ula-201901171013.

Petrov, A. N. (2016). Exploring the Arctic's "other economies": Knowledge, creativity and the new frontier. The Polar Journal, 6, 51-68. https://doi.org/10.1080/2154896x.2016.1171007

Petrov, A., \& Cavin, P. (2017). Creating new path creative capital: Theories and evidence in the northern periphery. The Journal of Rural and Community Development, 12(2/3), 127-142.

Puig de la Bellacasa, M. (2010). Ethical doings in nature cultures. Ethics, Place and Environment, 13, 151-169. https://doi.org/10.1080/13668791003778834

Rantala, O., Hallikainen, V., Ilola, H., \& Tuulentie, S. (2018). The softening of adventure tourism. Scandinavian Journal of Hospitality and Tourism, 18, 343-361.

https://doi.org/10.1080/15022250.2018.1522725

Rantala, O., \& Valkonen, J. (2011). The complexity of safety in wilderness guiding in Finnish Lapland. Current Issues in Tourism, 14, 581-593.

https://doi.org/10.1080/13683500.2010.548548

Rantala, O., \& Valtonen, A. (2014). A rhythmanalysis of touristic sleep in nature. Annals of Tourism Research, 47, 18-30. https://doi.org/10.1016/j.annals.2014.04.001

Regional Council of Lapland. (2015). Lapin matkailustrategia 2015-2018. Retrieved from http://www.lappi.fi/lapinliitto/c/document_library/get_file?folderld=2265071\&name=DLFE25498.pdf

Regional Council of Lapland. (2019). Aluekierrosten tulokset. [Results from regional workshops.] Tiedolla johtaminen -seminaari, 11 January 2019, Multidimensional Tourism Institute, Finland.

Richards, G. (2011). Creativity and tourism. Annals of Tourism Research, 38, 1225-1253. https://doi.org/10.1016/j.annals.2011.07.008

Robinson, R. N., Martins, A., Solnet, D., \& Baum, T. (2019). Sustaining precarity: Critically examining tourism and employment. Journal of Sustainable Tourism.

https://doi.org/10.108o/og669582.2018.1538230

Saarinen, J. (2003). The regional economics of tourism in northern Finland: The socio-economic implications of recent tourism development and future possibilities for regional development. Scandinavian Journal of Hospitality and Tourism, 3, 91-113.

https://doi.org/10.1080/15022250310001927

Saarinen, J. (2005). Tourism in the northern wildernesses: Wilderness discourses and the development of nature-based tourism in northern Finland. In C. M. Hall \& S. Boyd (Eds.), Nature-based tourism in peripheral areas: Development or disaster? (36-49). Clevedon: Channel View.

Saarinen, J., \& Gill, A.M. (2019). Tourism, resilience and governance strategies in the transition towards sustainability. In J. Saarinen \& A. M. Gill (Eds.), Resilient destinations: Governance strategies in the transition towards sustainability in tourism, (15-33). London: Routledge.

Sandell, K., \& Sörlin, S. (2000). Friluftshistoria: Från "härdande friluftslif" till ekoturism och miljöpedagogik: Teman i det svenska friluftslivets historia. Stockholm: Carlssons bokförlag.

Satokangas, P., \& Vieru, M. (2017). Majoitukset ja majoittujat Lapissa. In H. Ilola, P. Satokangas, \& M. Tapaninen (Eds.), Tilastoja tutkimassa - Lukuja Lapin matkailusta (19-30). Rovaniemi: Matkailualan tutkimus- ja koulutusinstituutti. 
Stephen, K. (2018). Societal impacts of a rapidly changing Arctic. Current Climate Change Reports, 4, 223-237. https://doi.org/10.1007/s40641-018-0106-1

Stewart, E. J., Howell, S. E. L., Draper, D., Yackel, J, . \& Tivy, A. (2007). Sea ice in Canada's Arctic: Implications for cruise tourism. Arctic, 60, 370-380.

Strauss, K. (2018). Labour geography II: Being, knowledge and agency. Progress in Human Geography. https://doi.org/10.1177/0309132518803420

Tervo, K. (2008). The operational and regional vulnerability of winter tourism to climate variability and change: The case of the Finnish nature-based tourism entrepreneurs. Scandinavian Journal of Hospitality and Tourism, 8, 317-332. https://doi.org/10.1080/15022250802553696

Tervo-Kankare, K. (2012). Climate change awareness and adaptation in nature-based winter tourism: Regional and operational vulnerabilities in Finland. Doctoral Thesis. (Nordia Geographical Publications 41:2.) University of Oulu, Department of Geography and Geographical Society of Northern Finland.

Tervo-Kankare, K., Hall, C. M., \& Saarinen, J. (2013). Christmas tourists' perceptions to climate change in Rovaniemi, Finland. Tourism Geographies, 15, 292-317. https://doi.org/10.108o/14616688.2012.726265

Tervo-Kankare, K., Kaján, E., \& Saarinen, J. (2018). Costs and benefits of environmental change: Tourism industry's responses in Arctic Finland. Tourism Geographies, 20, 202-223. https://doi.org/10.1080/14616688.2017.1375973

Tiller, R. G., Borgersen, Å. L., Knutsen, Ø., Bailey, J., Bjelland, H. V., Mork, J., . . Liu, Y. (2017). Coming soon to a Fjord near you: Future jellyfish scenarios in a changing climate. Coastal Management, 45, 1-23. https://doi.org/10.1080/08920753.2017.1237239

Times Colonist. (2019). Indigenous offerings becoming focus as 2018 breaks tourism record in Canada. Andrew Duffy, 22 February 2019. Retrieved from https://www.timescolonist.com/business/indigenous-offerings-becoming-focus-as-2018breaks-tourism-record-in-canada-1.23642199

Tourism Vancouver. (2019). Retrieved from https://www.tourismvancouver.com/plan-yourtrip/travel-tips-tools/what-to-wear/

Tuulentie, S., \& Heimtun, B. (2014). New rural residents or working tourists? Place attachment of mobile tourism workers in Finnish Lapland and Northern Norway. Scandinavian Journal of Hospitality and Tourism, 14, 367-384. https://doi.org/10.1080/15022250.2014.967998

Uriely, N. (2001). 'Travelling workers' and 'working tourists': Variations across the interaction between work and tourism. International Journal of Tourism Research, 3, 1-8. https://doi.org/10.1002/1522-1970(200101/02)3:1\%3C1::AID-JTR241\%3E3.0.CO;2-M

Uusitalo, M., Tuulentie, S., Kantola, S., Huhta, E., \& Nivala, V. (2018). Polkuja luontoon - Levin kesäreittiverkoston kehittäminen käyttäjäkokemuksia ja ekologista tietoa yhdistäen. Matkailututkimus, 14(2), 7-23.

Viken, A. (2013). What is Arctic tourism, and who should define it? In D. K. Müller, L. Lundmark \& R. H. Lemelin (Eds.), New issues in polar tourism: Communities, environment, politics (37-50). New York, NY: Springer.

Viken, A. (2014). Destinations discourses and the growth paradigm. In A. Viken \& B. Granås (Eds.), Tourism destination development: Turns and tactics (21-46). Farnham: Ashgate.

Viken, A., Granås, B., \& Nyseth, T. (2008). Kirkenes: An industrial site reinvented as a border town. Acta Borealia, 25, 22-44. https://doi.org/10.1080/08003830802302869

Vikhamar-Schuler, D., Isaksen, K., Haugen, J. E., Tømmervik, H., Luks, B., Schuler, T. V., \& Bjerke, J. W. (2016). Changes in winter warming events in the Nordic Arctic region. Journal of Climate, 297), 6223-6244. https://doi.org/10.1175/jcli-d-15-0763.1

Visit Finland. (2019). Statistics Service Rudolf. Retrieved from http://visitfinland.stat.fi/PXWeb/pxweb/fi/VisitFinland

Visit Northern Norway. (2018) Visjon og strategi. Retrieved from https://nordnorge.com/no/ansatte/?Bransje $=448$ 
Wall-Reinius, S., \& Bäck, L. (2011). Changes in visitor demand: Inter-year comparisons of Swedish hikers' characteristics, preferences and experiences. Scandinavian Journal of Hospitality and Tourism, 11(sup1), 38-53. https://doi.org/10.1080/15022250.2011.638207

Yukon Government. (2017). Yukon Winter Tourism Summit sparks discussion about enhanced winter tourism (11 December, press release). Retrieved from http://www.gov.yk.ca/news/17265.html

Yukon Government. (2018). Yukon Tourism Development Strategy - Sustainable tourism. Our path. Our future: 2018-2028. Retrieved from http://www.tc.gov.yk.ca/ 


\section{Sammanfattning}

Säsongsturismen genomgår en omfattande förändring över hela den nordliga polarregionen och uppmärksammas alltmer av destinationsplanerare och ekonomiska utvecklingsstrateger på alla nivåer, av researrangörer och de många verksamheter som i hög grad livnär sig på turism och av de värdsamhällen och invånare som uppmäter turismens potential till att ha både positiva och negativa följder. Det finns fyra huvudperspektiv utifrån vilka säsongsturismen kan betraktas som ett problem i Arktis. För det första problematiseras säsongerna ur samhällssynpunkt när de leder till utbrändhet bland lokalbefolkningen, när kraven från en kapitalistisk ekonomilogik står i kontrast till rytmen hos livsstilsentreprenörer, när samhällen och miljöer måste svara an till högsäsongstrycket och när utflyttning och stängda serviceställen hindrar - eller förhöjer - den känsla av identitet och tillhörighet som slår sig till ro under lågsäsongen. För det andra har säsongerna, ur arbetskraft- och sysselsättningssynpunkt, en negativ påverkan på bilden av turismen som en sektor som kan erbjuda givande, långsiktiga jobb och stärker istället bilden av turismsysselsättningen som otrygg och lågutbildad. Säsongerna gör det svårt att anställa personer med högre kompetens och kapacitet och drar istället till sig arbetare som ofta saknar lojalitetskänsla för en plats, eller i alla fall för en särskild arbetsgivare på en plats. Retentionsproblemen leder i sin tur till höga kostnader kopplade till det outtömliga behovet av att utbilda nyanställda. Säsongerna kan avgöra vilken sorts och antalet investeringar som görs av myndigheter och kommuner på platser, till exempel gällande boende. För det tredje finns det globala processer som påverkar säsongsproblemen, såsom "arktifiering", som förstärker besökares föreställning om Arktis som en kall och snöig destination. Det pekar på en ignorans för de distinkta nordliga årstiderna och utgör ett hinder för utvecklingen av samhällsbaserad kulturell och kreativ turism. Slutligen handlar ett fjärde perspektiv om de beräknade effekterna av globala klimatförändringar, vilka tros förstärka säsongsaspekterna i Arktis och lägga om kursen för en redan känslig region tillsammans med dess kapacitet att utveckla motståndskraft.

Vid sidan av problemfokuserade perspektiv kan säsongerna också definieras i positiva termer. Det finns till exempel fördelar att hämta i formandet av narrativ och upplevelser som stödjer sig på attraktionen hos distinkta arktiska säsonger. Följaktligen utgör de årliga livscyklerna och rytmerna hos platser, samhällen och miljöer grunden för småskaliga, livsstils- och urbefolkningsentreprenörer. För dem kan säsongsturismen vara en nödvändighet. Säsongerna möjliggör också för lokala samhällen att "ta en paus" från turister och från den påverkan som turister har på känslan av identitet och tillhörighet under högsäsongen. Dessutom kan säsongerna betraktas i positiv bemärkelse när de gör det möjligt för arbetare att förflytta sig och resa runt med säsongerna, vilket för närvarande kännetecknar en stor del av de turismsysselsättningar som erbjuds. Turismarbetets rörlighet drar till sig ombytliga 
unga personer som får sina behov tillgodosedda av de mångsidiga och tillfälliga äventyr som Arktis perifera områden erbjuder. Således är turismsektorn, kanske oavsiktligt, en icke-erkänd träningsskola för färdighetsutveckling och kunskapsbildning inom kundservice, i en rad andra säsongsorienterade sysselsättningssektorer (t.ex. gruvdrift, skogsbruk och vägbyggnation).

Utvecklandet av året-runt-turism kan leda till en stark turismtillväxt. De nyckelutmaningar som uppstår vid en stark tillväxt ligger $\mathrm{i}$ att hantera det högsäsongstryck som lokala samhällen och miljöer kommer att behöva möta. Om högsäsongen är för påfrestande kommer samhällen inte att vilja ha året-runt-turism, även om målet skulle vara att balansera ut säsongerna långsiktigt. Dessutom kan en turismtillväxt under nya säsonger göra det svårt för lokala aktörer att anpassa sig till reviderade samhällsrytmer och förändrade årliga platscykler (t.ex. inkräkta på de tillfällen som är avsedda för samhällsbygge, inte för besökare, vilka inträffar under månader med liten eller ingen turism). Vidare behöver året-runt-turismens sociokulturella och ekologiska påverkan beräknas för varje enskild region på grund av det arktiska områdets mångfald. Därav bör man ta hänsyn till varje enskilt samhälle genom att tillämpa "samhället först"-planeringar. Nyckelmöjligheter associerade med den starka tillväxten skildrar möjligheten att erbjuda högkvalitativa och året-runtsysselsättningar inom turismsektorn som stärker samhällen. Dessutom kan utvecklingen av året-runt-turism hjälpa lokalt ägda företag i medium och större storlek att konkurrera med externt ägda företag, vilket förhindrar överföringen av ägarandelar från lokala intressenter till internationella investerare och förhindrar situationer som medför konkurrens genom lägre prisnivåer. Vidare kan året-runt-turism medföra resurser som adresserar miljöproblem och höjer infrastrukturkvalitet.

Övergripande skulle året-runt-turism, i kontexten av det framtida arktiska Europa, kunna utgöra ungefär 9-10 månader av lönsam verksamhet, vilket fortfarande lämnar utrymme för en "återhämntningsäsong". Genom att engagera samhällen i turismutveckling, genom miljöomtanke och identifiering av specifika karaktärsdrag hos lokala kontexter och globala processer, kan en hållbar form av turism utvecklas där en återhämtningssäsong kanske inte behövs.

För att sammanfatta det hela behöver följande överväganden göras för att en blomstrande och hållbar turismsektor ska kunna utvecklas i det arktiska Europa: införa "samhället först"-planeringar; öka det lokala företags- och resursägandet - inklusive sociokulturellt orienterade resurser, till exempel festivaler eller ursprungskulturbaserade attraktioner och dra nytta av nya lokala innovationer för integrering av natur och kultur i turism; arbete- och sysselsättningsfrågor; skapa strategier för att minska arbetsotryggheten förknippad med turism; utbilda resenärer om hållbara arktiska sätt att leva, vilket också tar ansvar för hur livsstilsentreprenörskap uttrycks i Arktis; öka urbana arktiska turismmöjligheter; dra nytta av mångfalden i de distinkta säsongerna i Arktis; ta hänsyn till globala klimatförändringar och satsa på hållbar transport. 


\section{Rekommendationer}

- Betrakta säsongerna utifrån ett lokalsamhälleligt perspektiv så att långsiktig och hållbar utveckling av arktisk turism lutar sig mot en engagerad samhällsutveckling och omtanke för lokala miljöer. Detta förhållningssätt innebär mer specifikt att:

- Ramverket för hanteringen av säsongerna bör, inom ledning och beslutsfattande på regional och nationell nivå, överväga kontextspecifika situationer där året-runt-turism kan utgöra ett problem och/eller en möjlighet.

- Rumskänsliga strategier bör förstärkas med syfte att öka turismen i samhällen utanför kärnområdena, i periferin och i deras turism (t.ex. kringområden till Reykjavik, Island).

- Stärka bilden av och förståelsen för turismen som ekonomisk verksamhet och skapare av värdefull och rättvist kompenserad sysselsättning (SDG nr 8). Det skulle också på ett positivt sätt stödja turismen i sin integration med den arktiska sociala samhällsväven. Denna strategi skulle specifikt också:

- Förtydliga de olika karriärvägar som finns inom turism (t.ex. service, ekonomioch/eller samhällsplanering och utveckling samt marknadsföring av destinationer).

- Öka och marknadsföra värdet och statusen hos turismrelaterad sysselsättning (t.ex. skapa strategier och kampanjer som utmanar de insnävda definitionerna av turismsysselsättning som "lågavlönade ingångsjobb").

- Skapa sätt att fira det faktum att så många unga människor tar sig igenom universitetsutbildningar och skaffar sig livslång, överförbar professionalism och andra färdigheter när de arbetar i den här sektorn.

- Öka möjligheter för träning, utbildning och mentorskap.

- Fokusera på att höja kompetenserna hos den lokala arbetskraften.

- Arbeta med intressenter för att bekämpa utnyttjandet av billig arbetskraft (social dumpning) och anställningsotrygghet.

- Upprätta och implementera regelverk och lagstiftningsramar som speglar och stödjer mobila och dynamiska turismekonomier, vilket i sin tur skulle stärka destinationssamhällena (d.v.s. där turismen försiggår):

- Skapa stödsystem för småskaliga turismföretag i mikro-/nanostorlek att öka sin konkurrensnivå (innovationsnivå). Det är viktigt att ta hänsyn till turismföretagens olika behov och möjligheter, därför spelar ett flexibelt stöd en avgörande roll.

- Skapa nationella initiativ för turismpolitik som tar hänsyn till regionala skillnader och mångfalden av företag inom sektorn.

- Introducera en mekanism som säkerställer att inkomstskatt som betalas av säsongsarbetare stannar i samhället där de arbetar. 
- Balansera kraven under högsäsongerna med ökade ansträngningar för att utveckla produkter under kommande säsonger. Det skulle också hjälpa till att stabilisera arbetskraftstillgången:

- Förbättra kunskapsinnehåll och serviceaspekter av natur- och kulturbaserade verksamheter.

- Skapa turisterbjudanden under andra säsonger.

- Marknadsföra andra säsonger för högsäsongsturister.

- Utveckla en högsäsongsturism baserad på lokalsamhälleliga perspektiv och med olika bilder som representation för mångfalden hos arktiska innebörder och upplevelser:

- Undvika stereotyp produktion och marknadsföring av vinterturism som stärker den arktifierande processen och bilden av Arktis som kallt, snöigt och folktomt.

- Stödja utvecklingen av nya lokala innovativa integrationer av natur och kultur och utveckla turismen baserat på dessa.

- Utveckla adaptiv kapacitet och proaktiva motståndskraftorienterade åtgärder som påverkar klimatförändringen positivt:

- Öka medvetenheten om globala förändringar och dess lokala konsekvenser för arktiska turismdestinationer.

- Skapa variation bland marknader och turismupplevelser tillsammans med en diversifiering av turismsäsongerna.

- Utveckla hållbara styrningsmodeller inom arktisk turismdestinationsutveckling:

- Stärka kopplingarna mellan hållbara ledningsinitiativ och diskussioner när de uppstår i Arktis med turismutvecklingsprocesser, inklusive pan-cirkumpolärt och öst-till-väst-nätverksbyggande, kunskapsskapande och delning.

- Dra nytta av hållbara och ansvarstagande turisminitiativ inom ramverket för FN:s globala mål för hållbar utveckling (SDGs).

- Bredda den kunskapsbas och efterforskning som produceras och används i utvecklingen av tursimrelaterade innovationer. 
Nordic Council of Ministers

Nordens Hus

Ved Stranden 18

DK-1061 Copenhagen K

www.norden.org

\section{Arctic Tourism in Times of Change: Seasonality}

The seasonal nature of tourism is increasingly receiving the attention of various actors: tourism destination planners and economic development strategists at all levels, tour operators and the diverse businesses that significantly depend on tourism, and the host communities who negotiate tourism's potential to have both positive and negative impacts. The research report at hand identifies and discusses four main perspectives on the issues of seasonal tourism in the Arctic: local community perspectives; employment and workforce issues; the Arctification of northern tourism; and global environmental change. These themes form the key issues around which the challenges and opportunities related to seasonality of tourism can be placed and worked with. Based on the discussion, the report outlines recommendations related to developing a thriving and sustainable tourism sector in Arctic Europe. 